\title{
MASTER
}

\section{ECONOMIC ASSESSMENT OF USING NONMETALLIC MATERIALS IN THE DIRECT UTILIZATION OF GEOTHERMAL ENERGY FINAL REPORT}

February 1979

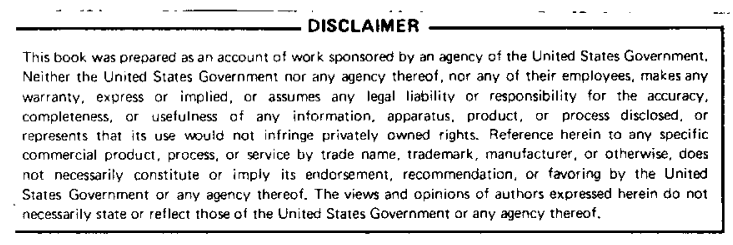

\section{Prepared by}

S.V. Cabibbo, R.M. Costello, and T. Ammerlaan

Burns \& Roe Industrial Services Corporation

Paramus, New Jersey

Under BNL Contract No. 442252-S

for the

PROCESS SCIENCES DIVISION

DEPARTMENT OF ENERGY AND ENVIRONMENT

\section{BROOKHAVEN NATIONAL LABORATORY \\ UPTON, NEW YORK 11973}




\section{DISCLAIMER}

This report was prepared as an account of work sponsored by an agency of the United States Government. Neither the United States Government nor any agency Thereof, nor any of their employees, makes any warranty, express or implied, or assumes any legal liability or responsibility for the accuracy, completeness, or usefulness of any information, apparatus, product, or process disclosed, or represents that its use would not infringe privately owned rights. Reference herein to any specific commercial product, process, or service by trade name, trademark, manufacturer, or otherwise does not necessarily constitute or imply its endorsement, recommendation, or favoring by the United States Government or any agency thereof. The views and opinions of authors expressed herein do not necessarily state or reflect those of the United States Government or any agency thereof. 


\section{DISCLAIMER}

Portions of this document may be illegible in electronic image products. Images are produced from the best available original document. 


\section{DISGLAIMER}

This book was prepared as an account of work sponsored by an agency of the United States Government. Neither the United States Government nor any agency thereof, nor any of their employees, makes any warranty, express or implied, or assumes any legal liability or responsibility for the accuracy, completeness, or usefulness of any information, apparatus, product, or process disclosed, or represents that its use would not infringe privately owned rights. Reference herein to any specific commercial product, process, or service by trade name, trademark, manufacturer, or otherwise, does not necessarily constitute or imply its endorsement, recommendation, or favoring by the United States Government or any agency thereof. The views and opinions of authors expressed herein do not necessarily state or reflect those of the United States Government or any agency thereof.

Printed in the United States of America Available from

National Technical Information Service U.S. Department of Commerce 5285 Port Royal Road Springfield, VA 22161

Price: Printed Copy $\$ 6.00$; Microfiche $\$ 3.00$ 


\section{ABSTRACT}

The Process Sciences Division of the Department of Energy and Environment at Brookhaven National Laboratory (BNL) has a lead role in a continuing effort to develop nonmetallic materials for geothermal applications. As part of this effort, Burns and Roe Industrial Services Corporation (BRISC) was awarded a contract to assess the cost effectiveness of such materials in three direct-use geothermal applications.

An extensive review of the available literature was conducted by BRISC in order to ascertain those processes for which sufficient design and cost data had been published to permit this economic assessment to be made. Only three such processes could be found and they are discussed herein. However, there are undoubtedly many other applications in which nonmetallic materials could be profitably utilized.

One report found in the literature described how geothermal processes may be utilized to provide heat to two agri-industrial processes, i.e., sugar beet refining and barley malting. Two alternative designs and cost estimates were presented in that report for each plant. The first design used all metallic materials with corrosion allowances. The second design incorporated a nonmetallic epoxy coating in lieu of the corrosion allowances. During the present study, BRISC developed a third design utilizing polymer concrete and estimated its cost.

A second report described four conceptual designs for a geothermal district heating piping system and presented cost estimates for each. Two of these utilized nonmetallic piping materials (fiber reinforced plastic and asbestos cement). In addition, BRISC developed an additional conceptual design and cost estimate utilizing polymer concrete.

The results of these studies indicate that significant cost savings can be achieved by using nonmetallic materials in processes utilizing low to moderate $\left(300^{\circ} \mathrm{F}\left[149^{\circ} \mathrm{C}\right]\right.$ ) temperature water. 
SECTION NUMBER AND TITLE $\quad$ Page

ABSTRACT . . . . . . . . . . . . . . . . . $1 i i$

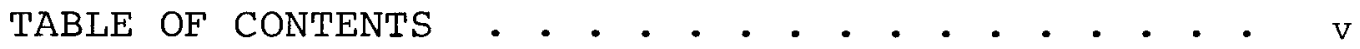

LIST OF FIGURES • • • • • • • • • • • • • • • • • vi

LIST OF TABLES • • • • • • • • • • • • • • • • • • vii

I EXECUTIVE SUMMARY • • . . . . . . . . . . . . . . 1

II CONCLUSIONS • • • • • • • • • • • • • • • • 5

III RECOMMENDATIONS • • • • • • • . • • • • • • • 8

IV INTRODUCTION . • • • • . . . . . . • . . . . . 10

$\mathrm{V}$ MATERIAL ASSESSMENT AND DEVELOPMENT NEEDS • • • 18

VI DESCRIPTION OF PLANTS . . . • . • • . . • • . 23

Sugar Beet Refining Plant . . . . . . . . . . 23

Base Design (Corrosion Allowance on Steel . . 23

Polymer Concrete Design . . . . . . . . 29

Epoxy Coating Design . . . . . . . . 30

Barley Malting Plant . . . . . . . . . 30

Base Design (Corrosion Allowance on Steel). • 30

Polymer Concrete Design . . . . . . . . 35

Epoxy Coated Design . . . . . . . • • 36

District Heating System, Klamath Falls, Oregon. • 36

Steel Pipe in Concrete Trench . . . . . . 39

Steel Pipe - Directly Buried . . . . . . 40

FRP Pipe - Directly Buried . . . . . . . . 40

Asbestos Cement Pipe - Directly Buried • . . 42

Polymer Concrete Pipe - Directly Buried . . . 42

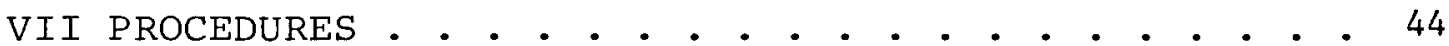

VIII RESULTS OF STUDY . • . • . • • • • • • • • . 57

Sugar Beet Refining . . . . . . . . . . 57

Barley Malting Process . . . . . . . . 59

District Heating System . . . . . . . . 63 
TABLE OF CONTENTS

(Continued)

SECTION NUMBER AND TITLE

$\underline{\text { Page }}$

IX REFERENCES • • • • • • • • • • • • • • • • • • 73 APPENDIX

SOLID POLYMER CONCRETE VESSELS AND TANKS • • • • • 75

\section{LIST OF FIGURES}

Figure No.

Title

$\underline{\text { Page }}$

1

Pretreatment Plant, Sugar Beet Process • • 12

2

Flash Tank Flow Schematic, Sugar Beet Process . . . . . . . . . . . 13

Pretreatment Plant, Barley Malting Process. . . . . . . . . . . 14

General Schematic of Barley Malting

Process. . . . . . . . . . . . . 15

5

District Heating System - Piping Plan . • 17

6

District Heating System - Concrete Trench - 41

District Heating System - Trenching . . . 41 


\section{IIST OF TABLES}

Table No.

Title

Page

1

2

4

5

6.

7.

8.

9 .

10.

11.

12.

13.

14 .

15.

16.

Vessel Design Conditions Sugar Beet Process . . . . . . . • • 24

Sugar Beet Process - Design and Cost Comparison, Base Metallic Design versus Polymer Concrete Design . • • • • . 26

Sugar Beet Process - Design and Cost Comparison, Base Metallic Design versus Epoxy Coated Design. . . . . . . . . . 31

Vessel and Piping Design Conditions Barley Malting Process . . . . . . . 32

Barley Malting Process - Design and Cost Comparison, Base Metallic Design versus Polymer Concrete Design . . . . . . .

Barley Malting Process - Design and Cost Comparison, Base Metallic Design versus Epoxy Coated Design . . . . . . . . 37

Pipe Unit Costs. • . . . . . . . • . 47

District Heating System - Piping Systems

Capital Cost Comparison .. . . . . 48

Asbestos Cement Pipe - Design and Cost Data. 49

Polymer Concrete Pipe - Design and Cost Data 52

Cost Comparison - AC Pipe versus PC Pipe . . 54

Cost Estimate for PC Pipe in Concrete Trench (Case 6) •. • . . . . . . 55

Sugar Beet Plant - Capital Cost Comparison - 58

Sugar Beet Plant - Energy Cost Comparison. • 60

Barley Malting Plant - Capital Cost Comparison

Barley Malting Plant - Energy Cost Comparison 


\section{LIST OF TABLES}

(Continued)

Table No.

Title

$\underline{\text { Page }}$

17. District Heating System - Capital Costs for Direct Buried Piping • • • • • • • • • 64

18. District Heating System - Capital Costs for Piping in Concrete Trench . . . . . 65

19. District Heating System - Energy Cost for Direct Buried Piping Systems . . . . 66

20 .

District Heating system - Energy Cost for Piping in Concrete Trench. . . . . • 67

21. Projected Direct Utilization of Geothermal Energy - Rocky Mountain Basin and Range Region . . . . . . . . . . . 69

22 . Energy Cost Savings versus Annual Cost Savings Based on Projected Direct Utilization of Geothermal Energy in the Rocky Mountain Basin and Range Region 
Applied research and development and technical management of the Department of Energy (DOE) national program on development of nonmetallic materials of construction for geothermal applications is being performed by Brookhaven National Laboratory (BNL). As part of this effort, Burns and Roe Industrial Services Corp. (BRISC) was engaged to assess the cost effectiveness of these materials in three processes which were designed for direct utilization of geothermal energy. The results of this assessment indicate that significant cost savings could be achieved by using nonmetallic materials in processes utilizing water at temperatures up to about $300^{\circ} \mathrm{F}\left(149^{\circ} \mathrm{C}\right)$.

An extensive review of the available literature was conducted by BRISC in order to ascertain those processes for which sufficient design and cost data had been published to permit this economic assessment to be made. Only three such processes could be found as of september 1978, and they are discussed herein. While there are undoubtedly many other applications in which nonmetallic materials could be profitably utilized, the published design and cost data for these applications was not detailed enough to permit a comparative cost estimate to be made.

Coury and Associates, Inc. (I) developed complete process details for the production of 5000 tons/day (4536 tons/day) of crystal sugar from beets and for malting 4 million bushels/yr (141 million $1 / \mathrm{yr}$ ) of barley for use in the brewing industry. In both cases, the process has been adapted to use a geothermal fluid as the main process energy source. 
LLC Geothermal Consultants performed a conceptual design study for a geothermal district heating system in Klamath Falls, Oregon. (2) Four different piping material (metallic and nonmetallic) combinations were considered in their study.

In addition to the nonmetallic designs included in References 1 and 2, BRISC has developed a conceptual design and cost estimate for each of the three processes utilizing polymer concrete (PC) linings on vessels and solid PC pipes.

The results of the comparative estimates presented herein indicate that a significant cost savings could be obtained through the use of nonmetallic materials in the design of direct utilization geothermal processes. The capital cost savings range from $\$ 100,000-\$ 250,000$ per plant (35-43\%) for the two food processing plants and $\$ 180,000-$ $\$ 260,000$ (13-27\%) for the district heating system. In terms of energy cost, the savings are $\$ .050 / 10^{6} \mathrm{Btu}\left(\$ .047 / 10^{9} \mathrm{~J}\right)$ or 2 percent for the two food processing plants and $\$ 0.30 / 10^{6}$ Btu $\left(\$ .28 / 10^{9} \mathrm{~J}\right)$ or $13 \%$ for the district heating system. The projected direct utilization of geothermal energy in the Rocky Mountain Basin and Range Region of the USA by the year $2000^{(3)}$ is $10^{15} \mathrm{Btu} / \mathrm{Yr}\left(1.0545 \times 10^{18} \mathrm{~J} / \mathrm{yr}\right)$. Based on this figure, the energy cost savings are equivalent to an annual savings of $\$ 50,000,000$ to $\$ 300,000,000$. If other direct use geothermal resources are verified, such as the Atlantic Coastal plain, additional savings would be achievable.

With one exception, the energy cost savings presented above resulted solely from the estimated savings in capital costs associated with the use of nonmetallic materials. All other operating costs (i.e., electrical power, chemicals, maintenance, etc.) for the three processes were considered equal for the metallic and nonmetallic designs. The excep- 
tion concerns the district heating system for which the stated energy cost savings includes the increased maintenance costs estimated by LLC Geothermal consultants ${ }^{(2)}$ for the nonmetallic piping alternatives relative to the steel. However, it is reasonable to expect that these maintenance costs would be basically the same for any of the materials considered. Assuming the maintenance costs are equal, energy cost savings for the district heating system would increase from $\$ 0.30 / 10^{6} \mathrm{Btu}\left(\$ 0.28 / 10^{9} \mathrm{~J}\right)$ to $\$ 0.38 / 10^{6} \mathrm{Btu}$ $\left(\$ 0.36 / 10^{9} \mathrm{~J}\right)$.

From these results it is concluded that the potential economic advantages warrant further developmental efforts on the nonmetallic materials to resolve the outstanding technical issues. Other conclusions are:

1. The cost of an epoxy coating or a PC lining on carbon steel tanks and pressure vessels is less than the cost of providing adequate corrosion allowances for many geothermal applications.

2. The use of prestressed and reinforced solid PC tanks and vessels may result in a cost savings of 50-70 percent relative to the cost of carbon steel units with a PC lining. A more detailed feasibility study of this approach should be performed.

3. Available data indicates that for pipe sizes 20 in. $(508 \mathrm{~mm})$ and under, asbestos cement or solid PC pipe is more economical than carbon steel pipe even for geothermal applications where corrosion is not a major consideration. The same applies to fiberglass reinforced plastic (FRP) pipe in sizes up to $8 \mathrm{in.}(203 \mathrm{~mm})$. However, further technical development is required before such pipes could be specified commercially for these applications. 
Some of the technical issues on which further work is recommended are:

1. Development of nonmetallic joint designs able to withstand the thermal and pressure stresses at a temperature of $325^{\circ} \mathrm{F} \quad\left(163^{\circ \mathrm{C}}\right)$.

2. Expansion joints for long nonmetallic pipelines.

3. Resistance to erosion and cavitation type damage (flashing fluids).

4. Ability to mass-produce large diameter pipes (up to 24 in. (610 mm) from FRP, PC, etc.) which are suitable for pressures of $150 \mathrm{psig}(1.03 \mathrm{MPa})$ and temperatures of $325^{\circ} \mathrm{F}$ $\left(163^{\circ} \mathrm{C}\right)$.

5. Adherence of the nonmetallic lining or coating to the surface of the vessel or pipe for the life of the project $(20-30$ years).

Work has already been started on some of these areas, and it is reasonable to expect that practical solutions can be found to all of these technical problems. 


\section{CONCLUSIONS}

Based on the results of this investigation, it is concluded that the total cost of the vessels and piping in typical geothermal fluid systems could be reduced significantly through the use of nonmetaliic materials. The estimated savings for the sugar beet plant are indicated below:

\begin{tabular}{lll} 
Metallic & Epoxy Lined & PC Lined \\
Design w/ & Vessels \& & Vessels \& \\
Corr. Allow. & PC Pipe & PC Pipe \\
\hline
\end{tabular}

Cost of Vessels \&

Piping (Delivered)

oSavings

$\$ 566,030$

$\$ 321,720$

$\$ 370,430$

Base

43 응

$35 \%$

The above capital cost savings translate to a reduction in energy cost of $\$ .05-\$ .06 / 10^{6} \mathrm{Btu}\left(\$ .047-\$ .057 / 10^{9} \mathrm{~J}\right)$, which represents a savings of about $2 \%$. The impact on energy cost appears relatively low because the total cost of the vessels and piping discussed only represents about 5\% of the total geothermal plant capital cost.

Similarly, for the barley malting plant, the savings attributable to the use of nonmetallic materials are shown below:

\section{Metallic Design w/ Corr. Allow}

Cost of Vessels \& Piping (Delivered)

\%Savings

$$
\$ 150,590
$$

Base

$$
\begin{aligned}
& \text { Epoxy Lined } \\
& \text { Vessels \& } \\
& \text { PC Piping } \\
& \hline
\end{aligned}
$$

$$
\$ 92,600
$$

$39 ㅇ$
PC Lined Vessels \& PC Pipe

These capital cost savings for the barley malting plant are equivalent to an energy cost savings of $\$ .05-\$ .06 / 10^{6}$ Btu $\left(\$ .047-\$ .057 / 10^{9} \mathrm{~J}\right)$ which is a savings of $2 \%$. 
In the district heating system study, two types of inground pipe installation alternatives were discussed. The first was a direct burial approach where the pipe and insulation were enclosed in a protective jacket. The second alternative involved installation of the insulated pipe in a concrete box or trench which had a removable top for access. For each installation alternative, the following tables compare the estimated piping system costs for various metallic and nonmetallic piping materials:

\section{Direct Burial}

\begin{tabular}{llll} 
Steel Pipe & FRP Pipe & AC Pipe & PC Pipe \\
FRP Jacket & FRP Jacket & AC Jacket & PC Jacket \\
\hline
\end{tabular}

Cost of Piping

$\&$ Insulation

(Installed)

$\$ 956,000$

$\$ 969,000$

$\$ 726,000$

$\$ 698,000$

\% Savings

Base

-1 응

$24 \%$

$27 \%$

Concrete Trench

Cost of Piping

\& Insulation

(Installed) $\$ 1,364,000$

$-\quad \quad-\quad \$ 1,183,000$

\% Savings

Base

13

For the direct burial case, the energy cost savings attributable to the use of AC or PC pipe in lieu of steel are $\$ 0.26 / 10^{6} \mathrm{Btu}\left(\$ .25 / 10^{9} \mathrm{~J}\right)(12 \%)$ and $\$ 0.30 / 10^{6} \mathrm{Btu}$ $\left(\$ 0.28 / 10^{9} \mathrm{~J}\right)(13 \%)$ respectively. For the concrete trench case, the energy cost savings obtained by using PC pipe is $\$ 0.25 / 10^{6}$ Btu $\left(\$ 0.24 / 10^{9} \mathrm{H}\right)(9 \%)$.

It should be noted that, based on the projected direct utilization of geothermal energy in the USA by the year $2000,{ }^{(3)}$ the energy cost savings indicated above are equivalent to an annual savings of $\$ 50,000,000$ to $\$ 300,000,000$. 
Other conclusions drawn from this study are as follows:

1. The cost of epoxy coating or PC linings on carbon steel tanks and pressure vessels is less than the cost of providing adequate corrosion allowances for many geothermal applications.

2. The use of prestressed and reinforced solid PC tanks and vessels may result in a cost savings of 50-70\% relative to the cost of carbon steel units with a PC lining. A more detailed feasibility study of this approach should be performed.

3. Available data indicates that for pipe sizes 20 in. $(508 \mathrm{~mm})$ and under, asbestos cement or solid PC pipe is more economical than carbon steel pipe for geothermal applications, even where corrosion is not a major consideration. The same applies to Fiberglass Reinforced Plastic (FRP) pipe in sizes

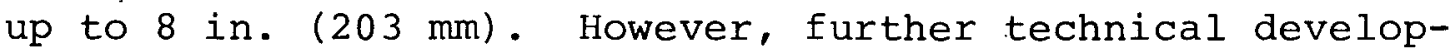
ment is required before AC, FRP, and PC pipes could be specified commercially for these applications.

4. The use of solid PC pipes may be more economical than PC linings for sizes up to $20 \mathrm{in.}(508 \mathrm{~mm})$ in diameter, assuming practical solutions to the technical issues discussed earlier can be found.

5. While the results of this study indicate that large FRP pipe is equivalent in cost to steel pipe, the former may have an advantage in systems handling more corrosive fluids where corrosion allowances would be required on the steel pipe.

6. Further improvements in the tensile strength of $P C$ pipe will further enhance the attractiveness of using it. 


\section{RECOMMENDATIONS}

This study has indicated that the economic potential of nonmetallic materials in geothermal fluid and other hot water service is very favorable. In order to provide data which will be required before these materials can be commercially specified for these applications, it is recommended that further work be carried on in the following areas:

1. Development of joint designs on nonmetallic vessels and pipes which are able to withstand the thermal and pressure stresses at a temperature of $325^{\circ} \mathrm{F}\left(163^{\circ} \mathrm{C}\right)$.

2. Development of expansion joints for long nonmetallic pipelines.

3. Development of a method to commercially produce pipes up to $24 \mathrm{in.}(610 \mathrm{~mm})$ in diameter from FRP, PC, AC, etc. which are suitable for pressures of 150 psig (1034 kPa) and temperatures of $325^{\circ} \mathrm{F}\left(163^{\circ} \mathrm{C}\right)$.

4. Acquisition of data on the resistance of PC, FRP, asbestos cement, and polymer linings to damage from vibration, water hammer, thermal cycling, thermal expansion, flashing fluids, erosion, cleaning solutions that may be used for mineral scale removal, and abrasion from mechanical cleaning equipment such as moles or high pressure jet lances.

5. Development of specific cost data for the commercial production of plain solid PC pipe and insulated solid PC pipe with a solid PC jacket as a function of diameter and wall thickness.

6. Investigation of the technical and economic potential of prestressed and reinforced polymer concrete pressure vessel and pipe construction. 
7. Development of repair procedures for spalled, cracked, chipped or otherwise damaged nonmetallic materials that can be accomplished in the field and in restricted areas, and possibly under adverse environments.

8. Development of application procedures whereby the thickness of PC linings can be reduced to only that required to form an impermeable barrier. This work is in progress and results to date indicate that $3 / 8 "(9.5 \mathrm{~mm})$ thickness is sufficient. For purposes of this study, a 1/2" (12.7 $\mathrm{mm}$ ) thickness has been assumed.

9. Improvement of the tensile strength of PC for use in pressure vessels and piping by inclusion of steel or glass reinforcing fibers.

10. Acquisition of a complete set of mechanical and thermal data for the range of conditions anticipated should be developed including thermal conductivity, expansion coefficients, tensile and compressive strengths, Poissons Ratio, Youngs Modulus, etc.

Work has already been started on some of these areas, and it is reasonable to expect that practical solutions can be found to all of the technical problems indicated above. 


\section{INTRODUCTION}

Scope of Work

Under contract to Brookhaven National Laboratory, BRISC has evaluated the use of nonmetallic material in processes which directly utilize geothermal energy. The scope of work under this contract was as follows:

A. With the assistance and approval of the Brookhaven project leader, BRISC identified and selected (by means of interviews and a literature survey) three (3) feasible design concepts for processes which represent potential near-term (ten (10) year) applications for the direct use of geothermal energy.

B. BRISC identified those structures where nonmetallic materials could technically and economically be employed in the processes selected above.

C. BRISC performed economic studies to determine the economic advantages of employing the nonmetallic materials in the services defined above.

This report summarizes the results of BRISC's efforts. The report includes all the study data and assumptions, and summarizes the cost impact of nonmetallic materials on the three (3) conceptual process designs selected.

Selected Processes

BRISC conducted an extensive literature search and numerous telephone and personal interviews in order to ascertain those processes for which sufficiently detailed design and cost data had been published to support this study. As of September 1978 only three such processes could be found and they are described herein. While there are undoubtedly many other applications in which nonmetallic materials 
could be profitably utilized, the published design and cost data for these were inadequate for this study.

Coury and Associates, Inc. (1)* developed and published complete process details for the production of crystal sugar from beets and for malting barley for use in the brewing industry. In each case, the process was adapted to use a geothermal fluid as the main process energy source.

In the sugar beet plant design (Figures 1 and 2), a brine feed at $302^{\circ} \mathrm{F}\left(150^{\circ} \mathrm{C}\right)$ was. flashed four times to provide steam for the various units of a four-effect evaporator unit, with the maximum and minimum flashed steam temperatures being $240^{\circ} \mathrm{F}\left(116^{\circ} \mathrm{C}\right)$ and $170^{\circ} \mathrm{F}\left(77^{\circ} \mathrm{C}\right)$ respectively. The limited initial flashdown available on the brine required that a large amount of brine be provided per unit steam production. A total of six production wells producing 4.60 $\times 10^{5} \mathrm{lbs} / \mathrm{hr}$ per well $\left(2.09 \times 10^{5} \mathrm{~kg} / \mathrm{hr}\right)$ and three injection wells were required. A spare was provided in each case. Prior to the flash vessels, a brine treatment procedure was included to prevent calcium carbonate scaling, which was expected to present the only scaling problem encountered for the typical brine chemistry selected. For this purpose the brine was neutralized with a 50 percent sulfuric acid solution to release carbon dioxide gas, and then treated with sodium hydroxide to raise the $\mathrm{pH}$ to noncorrosive levels.

In the barley malting plant (Figures 3 and 4 ), kilning was the major energy consuming operation. Drying of the malt was achieved by heating ambient air to temperatures ranging between $130^{\circ} \mathrm{F}\left(54^{\circ} \mathrm{C}\right)$ and $200^{\circ} \mathrm{F}\left(93^{\circ} \mathrm{C}\right)$ depending on the stage of the drying cycle that had been attained. For a plant

* Numbers in () indicate references listed in Section IX. 


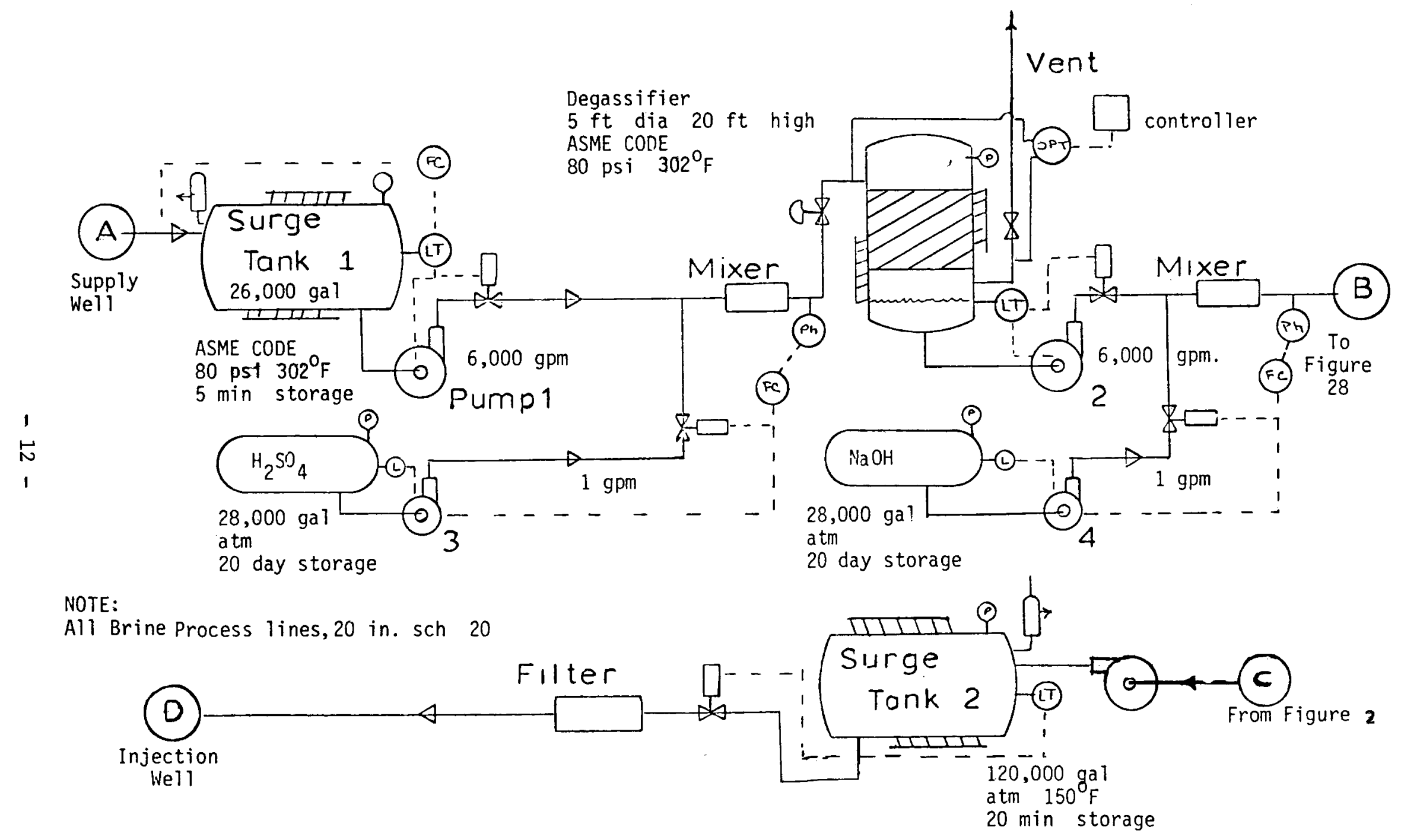

Figure 1. Pretreatment Plant, Sugar Beet Process 
Steam Lines to Evaporators

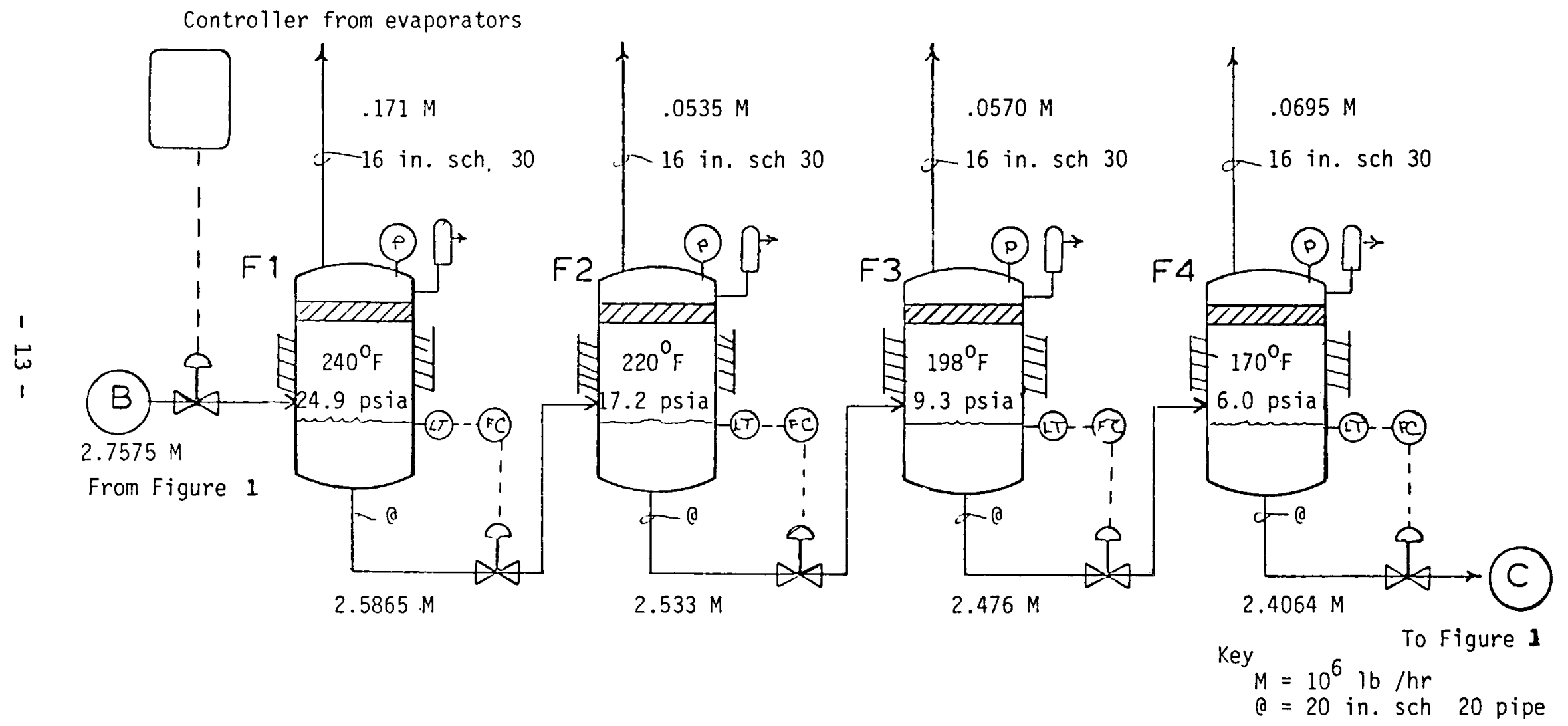

Figure 2. Flash Tank Flow Schematic, Sugar Beet Process 


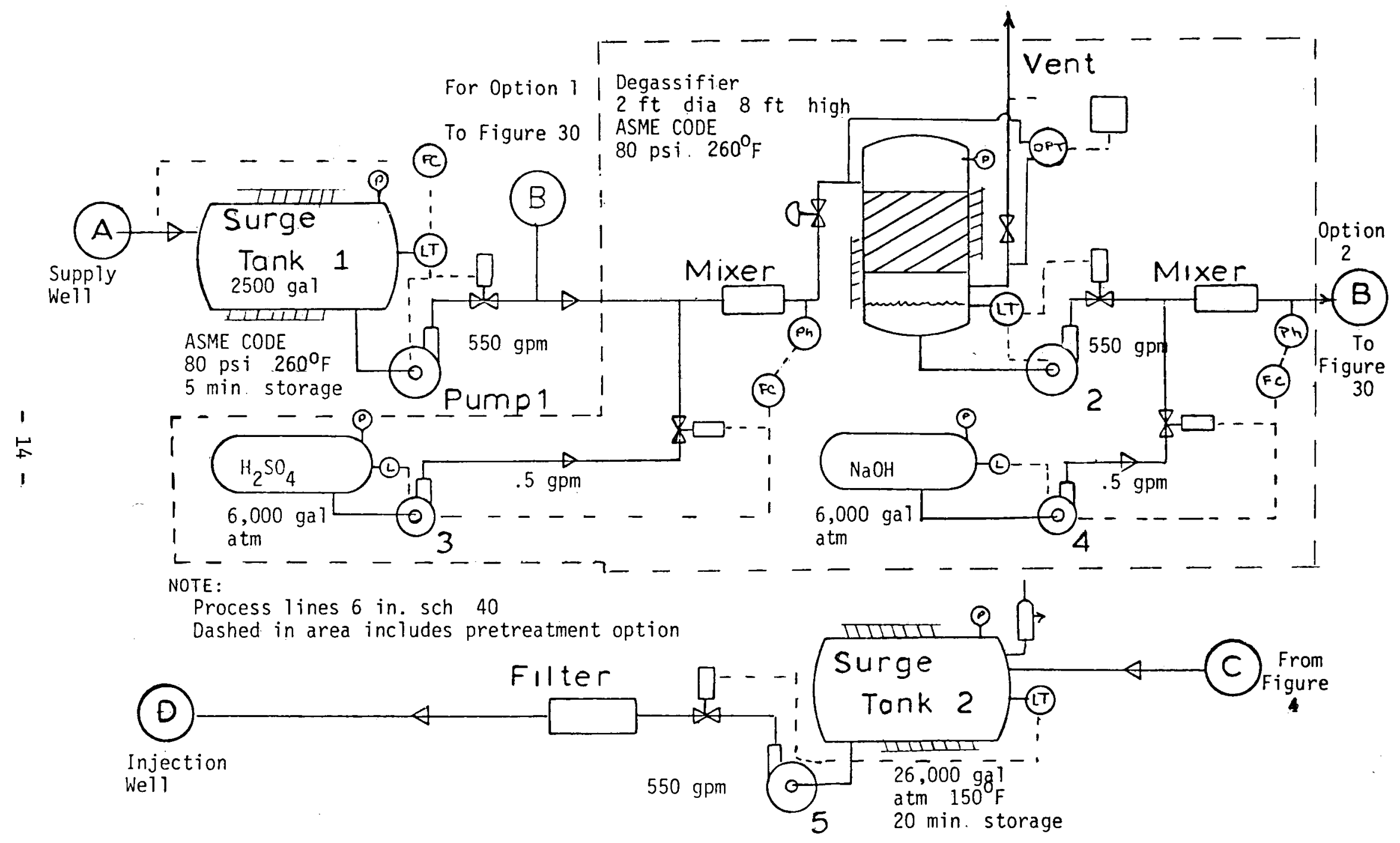

Figure 3. Pretreatment Plant, Barley Malting Process 


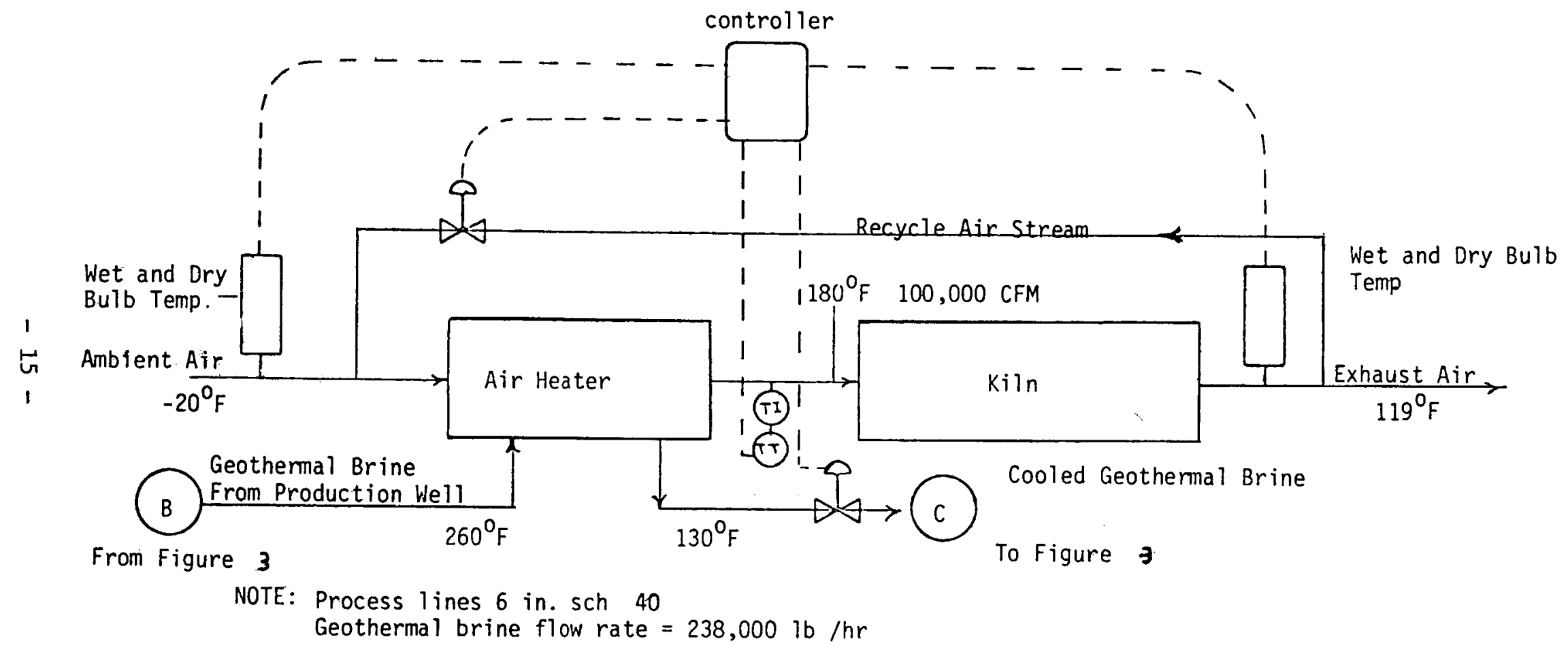

Figure 4. General Schematic of Barley Malting Process. 
capacity of four million bushels per year, the total plant fuel requirements ranged from 340,000 to 400,000 MBtu per year $(358,700$ to 422,000 billion Joules per year), $80 \%$ of which was consumed in the kiln.

Brine at $260^{\circ} \mathrm{F}\left(127^{\circ} \mathrm{C}\right)$ was transported from the wells by surface transfer lines to the plant battery limits. In the plant, the brine first entered a surge tank. The brine was then treated with sulphuric acid to limit scaling and routed to a degasifier for removal of $\mathrm{CO}_{2}$ gas. The final pretreatment with sodium hydroxide was intended to control the $\mathrm{pH}$ at a noncorrosive level. After pretreatment, the brine was routed to the tubeside of an air heater to heat ambient air for use in the kiln. After leaving the air heater, the brine was pumped via another surge tank to the reinjection wells.

LLC Geothermal Consultants performed a conceptual design study for a geothermal district heating system in Klamath Falls, Oregon. (2) In the district heating system, $225^{\circ} \mathrm{F}\left(107^{\circ} \mathrm{C}\right)$ fluid from the geothermal wells was supplied through a $16 \mathrm{in.}(406 \mathrm{~mm})$ underground insulated pipe to a central heat exchanger (see Figure 5) located 4060 ft (1237 m) from the wells. The design capacity of the wells was $6750 \mathrm{gpm}(25,540 \mathrm{l} / \mathrm{min})$. The length of the return lines for the cooled geothermal fluid was uncertain since the location of the reinjection well had not been determined. However, the first choice appeared to be use of an existing well near the planned heat exchanger site. Therefore, the length of this return pipe was neglected in the present study. A maximum of $1360 \mathrm{gpm}(5148 \mathrm{l} / \mathrm{min})$ of secondary water was heated in the exchanger to $180^{\circ} \mathrm{F}\left(82^{\circ} \mathrm{C}\right)$ and was routed to the business district where it was cooled and returned to the heat exchanger. The secondary system consisted of 4340 ft $(1323 \mathrm{~m})$ of $8 \mathrm{in.}(203 \mathrm{~mm})$ pipe, $4500 \mathrm{ft}(1372 \mathrm{~m})$ of 6 in. (152.4 mm) pipe, and $2720 \mathrm{ft}(829 \mathrm{~m})$ of $3 \mathrm{in.}(76 \mathrm{~mm})$ pipe. 


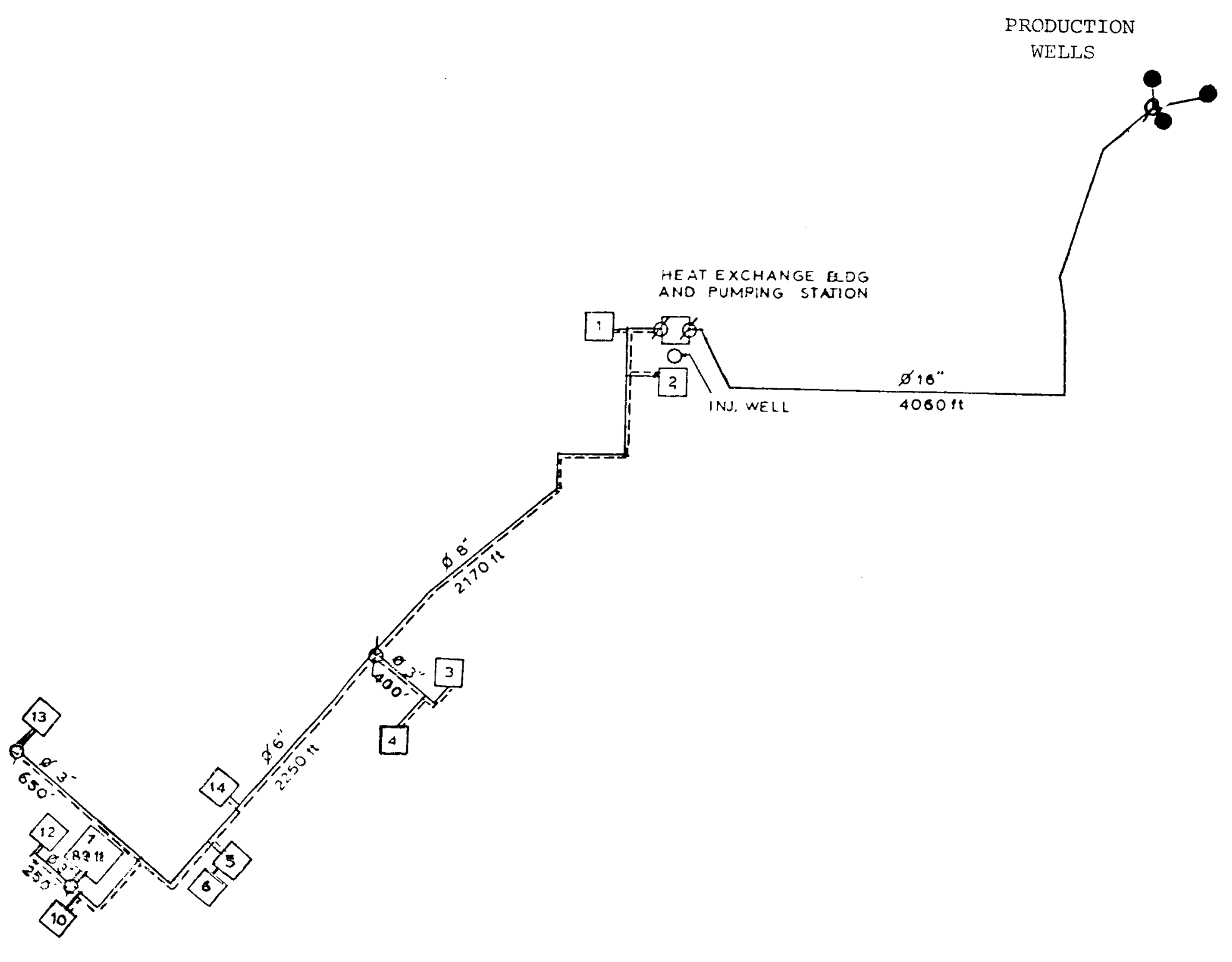

Figure 5. District Heating System; Piping Plan (Ref. 2) 
Geothermal sources for direct use seldom exceed $300^{\circ} \mathrm{F}$ $\left(149^{\circ} \mathrm{C}\right)$. At $300^{\circ} \mathrm{F}\left(149^{\circ} \mathrm{C}\right)$ and below, the amount of dissolved solids and gases in any geothermal fluid will be limited. Hence, a majority of the geothermal sources that have been identified so far for direct use applications are for all practical purposes noncorrosive in nature and permit the use of unprotected steel. Other direct use sources are only moderately corrosive, and unprotected steel can be used as long as some corrosion allowance or a protective coating (e.g., epoxy, etc.) is provided. In this study the San Luis valley goethermal source considered for the beet sugar and barley malting plants produces a moderately corrosive $300^{\circ} \mathrm{F}$ $\left(149^{\circ} \mathrm{C}\right)$ water while the $220^{\circ} \mathrm{F}\left(104^{\circ} \mathrm{C}\right)$ source for the Klamath Falls heating district is noncorrosive. The comparison of costs presented in this report shows that the use of nonmetallic materials such as polymer concrete (PC), asbestos cement, and fiberglass reinforced plastic (FRP) could reduce the cost of piping and vessels for direct use projects even if corrosion is not a factor in the design.

A review of the effect of geothermal fluids on carbon steel, which is normally one of the cheapest materials of construction available, shows that the rate of corrosion is a function of $\mathrm{pH}$, oxygen content and temperature. Corrosion is highest at $\mathrm{pH}$ values in the acid and highly alkaline regions, and minimal in the $\mathrm{pH} 5$ to $\mathrm{pH} 12$ region.

The rate of attack on carbon steel is usually taken to be in the range of $10 \mathrm{mils}(0.25 \mathrm{~mm})$ per year in saline water when the oxygen content is less than $1.0 \mathrm{ppm}$. These rates are greatly increased when oxygen is admitted to the system.

In the presence of hydrogen sulfide, even in trace amounts, the metal is exposed to further attack. 
BRISC operating experience indicates that carbon steel equipment functions adequately as long as oxygen is excluded from the system. When oxygen cannot be excluded (as during repair periods), the corrosion rate is greatly increased, being 3 to 10 times greater. Corrosion rates for carbon steels in seawater evaporators operating at temperatures up to $250^{\circ} \mathrm{F}\left(121^{\circ} \mathrm{C}\right)$ using sulfuric acid for scale control have had poor service records. One current practice is to not use carbon steel in contact with saline brine, but to rely on more costly metallic alloy linings or, in some cases, aluminum silicate cement concretes (Prekrete).

Based on results from laboratory and field tests, the technical feasibility of the use of polymer concretes (PC) as durable high strength construction materials in direct utilization processes has been demonstrated. PC is a mixture of organic monomers with inorganic ingredients similar to those used in portland cement concrete. These include sand, gravel and other fillers. For use in hydrothermal environments, reactive fillers, such as di- or tricalcium silicate that are generally added in the form of portland cement, are included in the aggregate. (4) The resulting PC has many properties superior to those made with hydrated portland cement. To date, monomer formulations such as 60 wt $\%$ styrene-40 wt $\%$ trimethylolpropane trimethacrylate (TMPTMA), 55 wt $\%$ styrene- 36 wt $\%$ acrylonitrile-9 wt $\frac{\circ}{0}$ TMPTMA and $50 \mathrm{wt} \%$ styrene-35 wt $\%$ acrylonitrile-5 wt acrylamide-10 wt $\%$ divinyl benzene have been shown to be highly durable to geothermal fluids. These systems can be polymerized using chemical initiators and heat or by chemical initiators and promoters.

Laboratory and preliminary field tests have shown that several PC formulations are suitable for use in medium to hot saline water applications under widely varying $\mathrm{pH}$ conditions and elevated temperatures. Resistance to corrosion is 
a function of the monomer and the aggregates used in compounding, and further testing is continuing to determine the optimum.

Field testing of $\mathrm{PC}$ mixtures at potential sites for direct utilization processes such as Klamath Falls, Raft River, Coso Hot Springs, and East Mesa has been in progress for more than one year. The maximum brine temperature in these tests is about $320^{\circ} \mathrm{F}\left(160^{\circ} \mathrm{C}\right)$. To date, essentially no deterioration or scale buildup has been detected.

The most severe test of materials for direct utilization processes is in progress at the East Mesa geothermal site. In one test, two $8 \mathrm{ft}(2.4 \mathrm{~m})$ sections of $\mathrm{PC}-1$ ined 3 in. $(76 \mathrm{~mm}) \mathrm{Sch} 40$ carbon steel pipe are being exposed to 60 to $80 \mathrm{gal} / \mathrm{min}(227-303 \mathrm{I} / \mathrm{min})$ of $26,000 \mathrm{ppm}$ brine at $320^{\circ} \mathrm{F}$ $\left(160^{\circ} \mathrm{C}\right)$. The PC liners are $0.5 \mathrm{in} .(13 \mathrm{~mm})$ thick and are composed of a 60 wt $\frac{\circ}{\circ}$ styrene-40 wt $\%$ TMPTMA monomer mixture used in conjunction with a 70 wt $\%$ sand-30 wt $\%$ Type III portland cement aggregate. One section has been exposed for eight months. A visual inspection of the section was made after exposure for 4,410 hours. No deterioration or scale accumulation was apparent. A layer of scale approximately 2 in. (51 mm) thick was reported to have accumulated on carbon steel pipe downstream of the PC test section after about 2000 hours of operation.

Based upon the above results, a second pipe section was installed downstream of the first section. A 5/8 in. (16 $\mathrm{mm}$ ) diameter orifice between the sections insures that the second pipe is exposed to flashing brine. After 1710 hours of testing, a visual inspection showed no scale accumulation or deterioration of the liner.

In February 1979 a 2 ft $(.61 \mathrm{~m})$ diameter by 6 ft $(1.8$ m) long prototype PC-lined carbon steel steam separator along with $30 \mathrm{ft}(9.1 \mathrm{~m})$ of $3 \mathrm{in.}(76 \mathrm{~mm}) \mathrm{sch} 40 \mathrm{pipe}$ and 
elbows were placed in test. Initial visual observations of the vessel indicated that the carbonate-type scale does not appear to adhere to the surface of the PC.

Test data are also available from testing of PC-lined pipe at Raft River. After exposure to a flowing brine at $302^{\circ} \mathrm{F}\left(150^{\circ} \mathrm{C}\right)$ for 15 months, no deterioration was apparent. Fiberglass reinforced plastic (FRP) pipe has excellent corrosion resistance, a low resistance to fluid flow, and is relatively easy to handle because of its light weight. Either epoxy or polyester resins are used. The more common types of resin and glass fiber will allow operation at temperatures of up to $270^{\circ} \mathrm{F}\left(132^{\circ} \mathrm{C}\right)$. If special epoxy or polyester resins are selected, operation to $400^{\circ} \mathrm{F}\left(204^{\circ} \mathrm{C}\right)$ is possible. Cost of the pipe depends on the resin being used, temperature and pressure. When the operating temperature is at the high end of the range that can be allowed for a particular resin, the wall thickness and consequently the cost of the pipe go up sharply with incremental temperature changes. Screwed and flanged joints are preferred and should be installed by experienced personnel. If installed properly, FRP piping systems will be trouble free. Experience with FRP pipe carrying hot water over a distance of more than a few hundred feet is limited.

Epoxy coatings can be applied quickly and inexpensively. Epoxy has a high resistance to corrosion. However, a good surface preparation is critical for obtaining the required adherence. Also, careful control of the coating thickness is required to eliminate possible porous spots that allow corrosion to occur in the steel.

A substantial number of epoxy coating failures have been reported due to blistering and subsequent peeling off of the coating. Its application is recommended only in slightly corrosive environments. 
An aluminum silicate cement (Prekrete) lining provides excellent corrosion resistance over a wide range, from dilute acid to dilute caustic. It can handle temperatures of up to $1000^{\circ} \mathrm{F}\left(538^{\circ} \mathrm{C}\right)$. Its coefficient of expansion is approximately the same as that of mild steel. Lining can be done in the field, but is relatively expensive. Factory lined vessels and pipes are commonly available, but they are heavy and generally penalized by high transportation costs. They also must be handled with care to prevent cracking or chipping of the lining. Therefore, long distance shipping of Prekrete lined vessels and pipe is usually uneconomical. For field lining, an experienced and licensed local contractor is a prerequisite. Failures of Prekrete linings have been associated with inadquate welding of the screens that are used to increase the bond between lining and steel. Repairs can be made in the field and are not difficult to accomplish.

Asbestos cement (AC) pipe has been extensively tested at the Raft River geothermal project. (5) In 1975, $4000 \mathrm{ft}$ $(1219 \mathrm{~m})$ of $\mathrm{AC}$ pipe was installed to transport $300^{\circ} \mathrm{F}\left(149^{\circ} \mathrm{C}\right)$ geothermal fluids at $150 \mathrm{psi}(1034 \mathrm{kPa})$. The experience has been satisfactory and it was recommended that AC pipe should be used for connecting future wells. At times this pipe was also used for transportation of cool water to a cooling pond, which resulted in rapid change in temperature inside the pipe. A number of pipe ruptures occurred because of the severe thermal shock. This situation has been corrected. The test also revealed the need for some modifications in trench design, better seal inspection, and better installation supervision. 


\section{DESCRIPTION OF PLANTS}

The design descriptions included herein for the sugar beet refining and barley malting plants have been extracted directly from Reference 1. They follow the geothermal brine from the production well, to the plant battery limit, through the process, and then to the reinjection well. It is assumed that downhole pressures are sufficient to produce artesian flow of the hot brines without flashing in the well, as appears to be generally the case in the San Luis Valley. Where this assumption is not valid, standard downhole pumps would be required. After being pumped to the plant, the brine process varies between the sugar and barley plants.

In a like manner, the district heating system design description presented below has been taken directly from Reference 2. Pumps are used to move the fluids in both the geothermal fluid (primary) system and in the secondary hot water system which carries heat from the central heat exchanger to the district being heated.

Sugar Beet Refining Plant

Base Design (Corrosion Allowance on Steel): In the beet sugar refining process, it is necessary to provide steam to the various juice evaporating stages. This steam is provided by flashing the geothermal brine in successive stages. Release of $\mathrm{CO}_{2}$ during the flashing could lead to scale formation and plugging of valves, lines, and nozzles. Accordingly, the brine is pretreated to permit controlled removal of $\mathrm{CO}_{2}$ and adjustment of the brine $\mathrm{pH}$, before reaching the flash stages.

The geothermal portions of this system are shown schematically on Figures 1 and 2. The design condition for the geothermal equipment and piping are given in Table 1. Table 2 
TABLE 1. VESSEL DESIGN CONDITIONS

SUGAR BEET PROCESS

Equipment

Capacity

Length

(ft)
20

51

$120,000 \mathrm{gal}$

1

Treatment Storage Tanks

1. Acid

2. Caustic

Degasifier

$28,000 \mathrm{gal}$

28,000 gal

22

22

20

Flash Tanks

Fl

F 2

F 3

F 4

Piping

*Vessel designed for full vacuum
Diameter

( $f t$ )
Temperature and Pressure Rating

SI Unit Conversions

$$
\begin{array}{ll}
1 \mathrm{gal} & =3.785 \mathrm{~L} \\
1 \mathrm{ft} & =0.3048 \mathrm{~m} \\
1 \mathrm{psi} & =6.894 \mathrm{kPa} \\
1 \mathrm{in} . \mathrm{Hg} & =3.386 \mathrm{kPa} \\
150^{\circ} \mathrm{F} & =65.6{ }^{\circ} \mathrm{C} \\
300^{\circ} \mathrm{F} & =149^{\circ} \mathrm{C}
\end{array}
$$


summarizes the design parameters and costs of the geothermal equipment and piping considered in this study.

Wellhead production is received in Surge Tank 1 from which it is pumped to the pretreatment site within the plant battery limits. The surge tank has a capacity of 26,000 gallons $(98,4101)$, which provides a residence time of about five minutes. The tank is of carbon steel construction with a $3 / 8$ in. $(9.5 \mathrm{~mm})$ corrosion allowance and is $20 \mathrm{ft}(6.1 \mathrm{~m})$ long by $15 \mathrm{ft}(4.6 \mathrm{~m})$ in diameter. Its design pressure is $80 \mathrm{psig}(552 \mathrm{kPa})$ at $300^{\circ} \mathrm{F}\left(149^{\circ} \mathrm{C}\right)$. The tank is blanketed with nitrogen gas when not operating under pressure to prevent air entry and to reduce the potential corrosion problems related to oxygen in the brine.

After leaving Surge Tank 1 , the brine is acidified by injection of $50 \%$ sulfuric acid upstream of a static in-line mixer. The acid is stored in a 28,000 gallon $(105,9801)$ tank constructed of carbon steel with a $1 / 8 \mathrm{in.}(3.2 \mathrm{~mm}$ ) corrosion allowance, and is maintained at ambient temperature and pressure. This supply is ample for about 20 days of operation. It is transferred by a gear pump made of Hastelloy, pneumatically operated at an average rate of about 1 gallon per minute $(3.7851 / \mathrm{min})$. The mixer is situated in the most corrosive area of the system and is constructed of titanium.

The brine $\mathrm{pH}$ is reduced to about 5.0 by acid injection to convert all the bicarbonate into dissolved $\mathrm{CO}_{2}$ gas. The $\mathrm{CO}_{2}$ is then stripped out of the brine by steam in a packedcolumn degassifier and is rejected to the atmosphere. Stripping steam is produced by partially flashing the hot brine, itself, in the top of the degassifier. The brine and steam then pass concurrently down through the packed section. 
TABLE 2. SUGAR BEET PROCESS

Design and Cost Comparison Base Metallic Design Versus Polymer Concrete Design

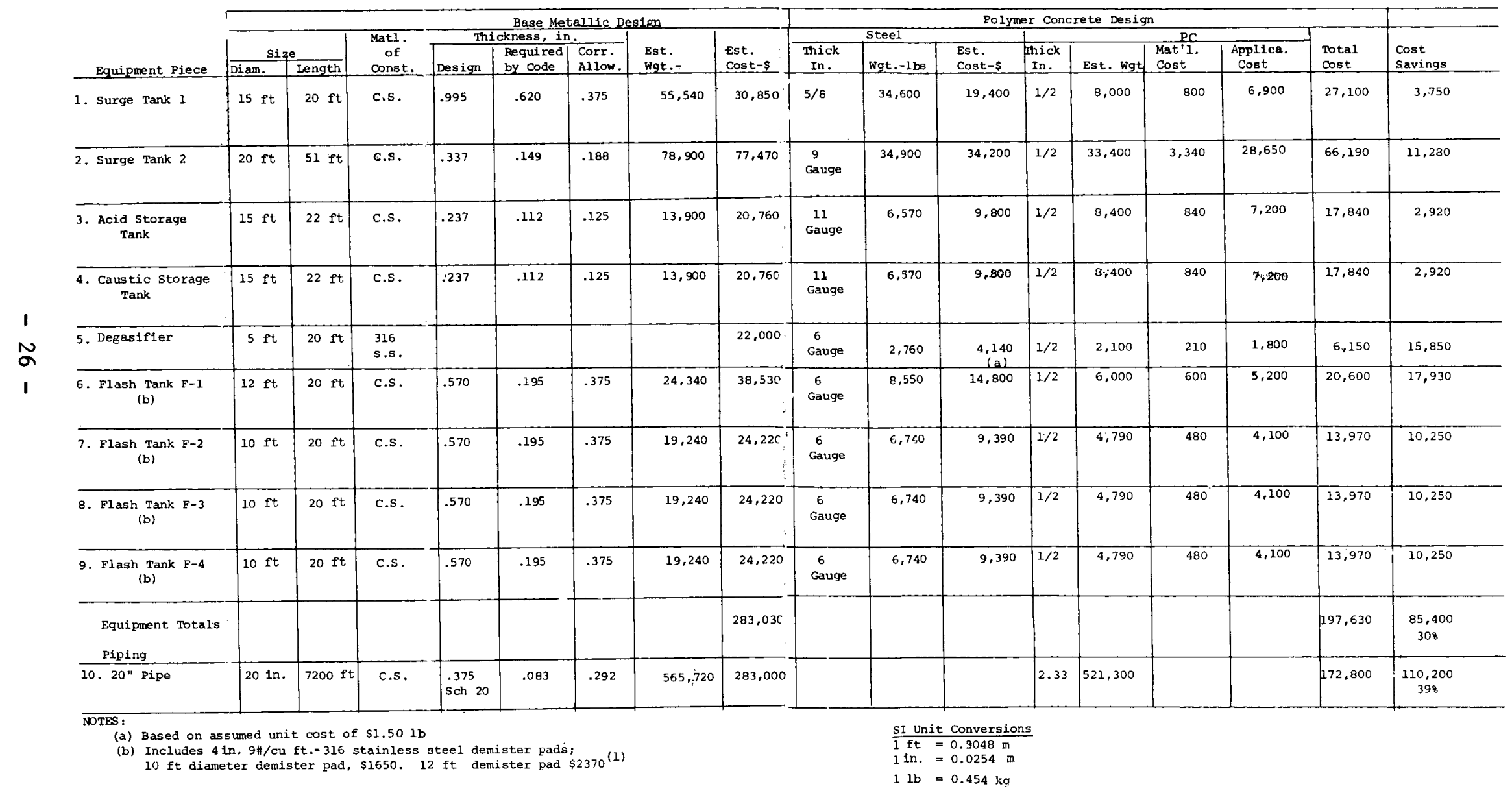


Degassified brine is collected in the column sump and pumped to the process. The flashed steam containing $\mathrm{CO}_{2}$ removed from the brine is vented to the atmosphere.

For the brine temperature of $300^{\circ} \mathrm{F}\left(149^{\circ} \mathrm{C}\right)$ and the bicarbonate concentration of 270 parts per million (ppm) about $1.378 \times 10^{4}$ pounds $(6250 \mathrm{~kg})$ per hour of steam are required at equilibrium to remove 95 percent of the $\mathrm{CO}_{2}$; the residual $\mathrm{CO}_{2}$ content of $13 \mathrm{ppm}$ is not expected to be a problem in subsequent processing. As a safety factor, the amount of steam produced by flashing has been increased 2 times, to $2.756 \times 10^{4}$ pounds $(12,500 \mathrm{~kg})$ per hour. This represents 1 percent by weight of the brine feed stream, and requires a flash down of $8^{\circ} \mathrm{F}\left(4.4^{\circ} \mathrm{C}\right)$ in the degassifier. Thus, decarbonated brine leaving the degassifier will be at a temperature of about $289^{\circ} \mathrm{F}\left(143^{\circ} \mathrm{C}\right)$.

A packed height of $5 \mathrm{ft}(1.52 \mathrm{~m})$ of ceramic saddle packing has been specified. The degassifier itself is about $5 \mathrm{ft}(1.52 \mathrm{~m})$ in diameter and $20 \mathrm{ft}(6.1 \mathrm{~m})$ tall. It is constructed of 316 stainless steel, and is designed to operate at $80 \mathrm{psig}(552 \mathrm{kPa})$ and $300^{\circ} \mathrm{F}\left(149^{\circ} \mathrm{C}\right)$.

To avoid corrosion of downstream equipment, the $\mathrm{pH}$ of the brine leaving the degassifier is increased to a safe operating level of 8 to 8.5 by the injection of 50 percent by weight caustic soda. The caustic is stored in a 28,000 gallon $(105,980$ 1) carbon steel tank which has a $1 / 8$ in. (3.2 mm) corrosion allowance and provides a 20-day storage capacity. The caustic is transferred by a pneumatically operated, stainless steel gear pump. Fluid mixing at the injection point is accomplished in a static, in-line mixer made of 316 stainless steel.

As shown on Figure 2, the treated brine then passes, successively, through flash tanks F1, F2, F3 and F4 where process steam is produced at the flow rates and temperatures 
indicated. Flashed steam passes through wire mesh demister pads installed in the tops of the vessels to remove entrained brine from the steam.

The flash vessels are all designed to operate at full vacuum, and at positive pressures ranging from 0 to 20 psig $(0$ to $130 \mathrm{kPa})$ and temperatures from $170^{\circ} \mathrm{F}$ to $240^{\circ} \mathrm{F}\left(77^{\circ} \mathrm{C}\right.$ to $\left.116^{\circ} \mathrm{C}\right)$. Vessels are constructed of carbon steel with a $3 / 8$ in. $(9.5 \mathrm{~mm})$ corrosion allowance. Vessel dimensions and demister specifications are given in Table 2.

Cooled brine leaving the last flash stage is collected in Surge Tank 2 prior to transfer to the injection well. Tank 2 is designed to operate at atmospheric pressure and $150^{\circ} \mathrm{F}\left(66^{\circ} \mathrm{C}\right)$ and has a capacity of 120,000 gallons $(454,200$ $1)$, which will provide 20 minutes of storage. It is constructed of carbon steel with a $3 / 16$ in. $(4.8 \mathrm{~mm})$ corrosion allowance and has overall dimensions of $51 \mathrm{ft}(15.5 \mathrm{~m})$ long by $20 \mathrm{ft}(6.1 \mathrm{~m})$ in diameter. Brine from the surge tank is pumped through a filter on the way to the injection well. All vessels have 2 in. $(50.8 \mathrm{~mm})$ of calcium silicate insulation.

Pipelines between the wells and the plant are designed for an operating pressure and temperature of 100 psig $(690$ $\mathrm{kPa})$ and $300^{\circ} \mathrm{F}\left(149^{\circ} \mathrm{C}\right)$, respectively. A $20 \mathrm{in.}(508 \mathrm{~mm}) \mathrm{Sch}$ 20 carbon steel line is required for the brine transfer lines, allowing a brine flow velocity of $6 \mathrm{ft}$ per second $(1.8 \mathrm{~m} / \mathrm{sec})$. A 16 in. $(406 \mathrm{~mm}) \mathrm{sch} 30$ carbon steel line was chosen for the steam transfer lines from the flash tanks to the evaporators. For the sake of presenting definitive numbers for this study, it is assumed that the wells are located 3,000 ft $(914 \mathrm{~m})$ from the plant. Within the pretreatment plant $1,200 \mathrm{ft}(366 \mathrm{~m})$ of $20 \mathrm{in}$. $(508 \mathrm{~mm})$ pipe is assumed and $400 \mathrm{ft}(122 \mathrm{~m})$ of $16 \mathrm{in.}(406 \mathrm{~mm}) \mathrm{Sch} 30$ is 
assumed for steam lines from the flash tanks. These distances will be different, of course, for most situations.

Polymer Concrete (PC) Design: The polymer concrete design developed by BRISC is the same as the base design described in the previous section with the following changes:

1. The thickness of all carbon steel vessels and tanks has been reduced by the amount of the specified (1) corrosion allowance. A $1 / 2$ in. $(12.7 \mathrm{~mm})$ thick layer of PC has been added to the inside surface of these vessels and tanks.

2. The 316 stainless steel degassifier vessel has been replaced by a carbon steel vessel lined with a $1 / 2$ in. $(12.7 \mathrm{~mm})$ thick layer of polymer concrete.

3. The 20 in. $(508 \mathrm{~mm}) \mathrm{Sch} 30$ carbon steel brine piping has been replaced with a $20 \mathrm{in.}(508 \mathrm{~mm})$ solid PC pipe.

No effort has been made in this study to evaluate or change the process design described in Reference 1 or the lengths, diameters, thicknesses and corrosion allowances specified in that report for tanks, vessels and piping. Therefore, our use of this data in the present analysis is not intended to imply our agreement with it. For each of the carbon steel vessels and pipes, Reference 1 specifies a design thickness and the corrosion allowance included in that thickness. Therefore, we have assumed that the difference between the two values is the thickness required by code without corrosion allowance (minimum code thickness), even though, in some cases, these minimum thicknesses seem to be less than code requirements. Since, as indicated above, the cost of the minimum thickness is common to both alternatives, it will not affect the incremental costs 
between the two approaches. The real trade-off is between the cost of the corrosion allowance and that of the polymer concrete lining.

Table 2 compares the equipment and piping specifications for the PC design with those of the base design.

Epoxy Coated Design: In addition to the base design described above, Coury and Associates, Inc. (I) also published a corresponding set of data for another design in which an epoxy coating is applied to the inside surface of all carbon steel vessels. This epoxy coating is used to protect the metallic surface from corrosion. Therefore, a very small allowance of $.025 \mathrm{in.}(.64 \mathrm{~mm})$ was specified for the coated vessels. (1) In addition to these changes, BRISC has substituted a $20 \mathrm{in.}(508 \mathrm{~mm})$ diameter solid PC pipe for the 20 in. $(508 \mathrm{~mm}) \mathrm{Sch} 30$ carbon steel pipe specified in the referenced report. With these exceptions, this design is the same as the base design.

Table 3 compares the equipment and piping specifications for the epoxy coated design with those of the base design.

Barley Malting Plant

Base Design (Corrosion Allowance on Steel): The base barley malting process is shown schematically in Figures 3 and 4. The design conditions for the geothermal brine equipment and piping are given in Table 4. Table 5 summarizes the design parameters and costs of the geothermal equipment and piping considered in this study.

Wellhead production at $260^{\circ} \mathrm{F}\left(127^{\circ} \mathrm{C}\right)$ is received in Surge Tank 1 from where it is pumped to the pretreatment system. The surge tank has a capacity of 2,500 gallons (9463 1) which provides a residence time of about five 
TABLE 3. SUGAR BEET PROCESS

Design and Cost Comparison Base Metallic Design Versus Epoxy Coated Design

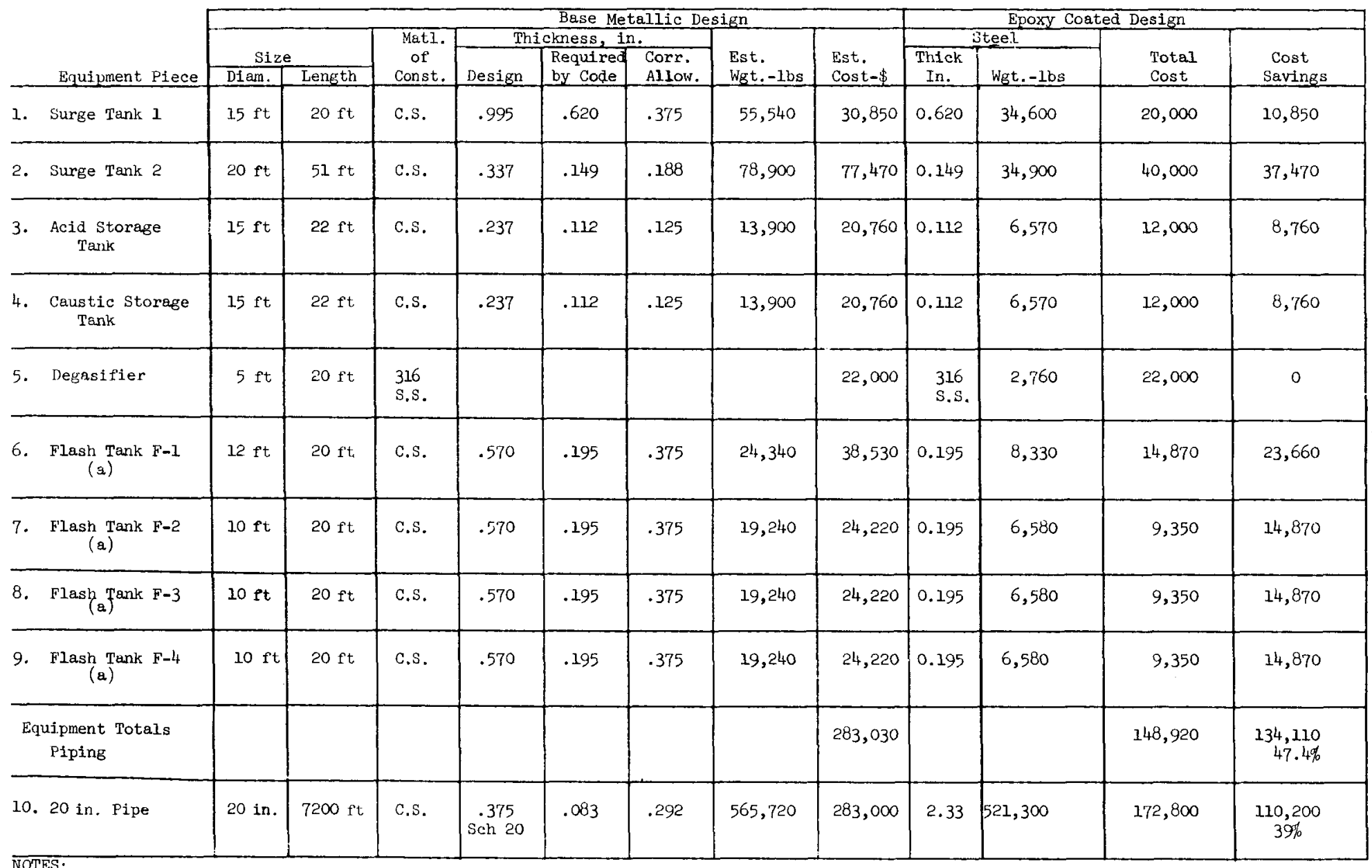
a) Includes $4 \mathrm{in.}$. $/ \mathrm{cu} \mathrm{ft} 316$ stainless steel demister pads;
$10 \mathrm{ft}$ diameter demister pad, $\$ 1650.12 \mathrm{ft}$ demister pad $\$ 2370$ 
TABLE 4

VESSEL AND PIPING DESIGN CONDITIONS

BARLEY MALTING PROCESS

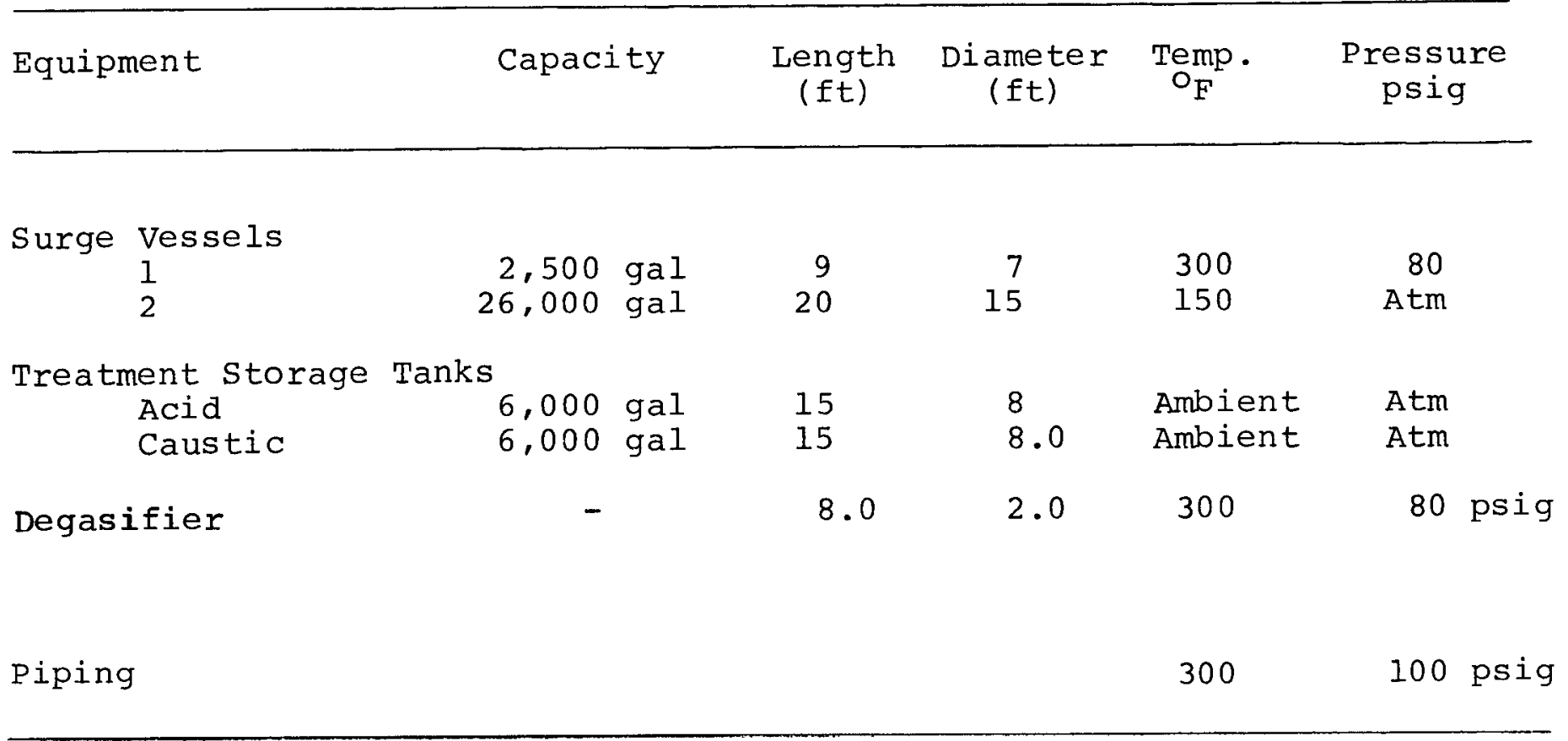

$\underline{\text { SI Unit Conversions }}$

$1 \mathrm{gal}=3.785 \mathrm{~L}$
$1 \mathrm{ft}=0.3048 \mathrm{~m}$
$1 \mathrm{psi}=6.894 \mathrm{kPa}$
$150^{\circ} \mathrm{F}=65.6^{\circ} \mathrm{C}$
$300^{\circ} \mathrm{F}=149^{\circ} \mathrm{C}$


TABLE 5. BARLEY MALTING PROCESS

Design and Cost Comparison Base Metallic Design Versus Polymer Concrete Design

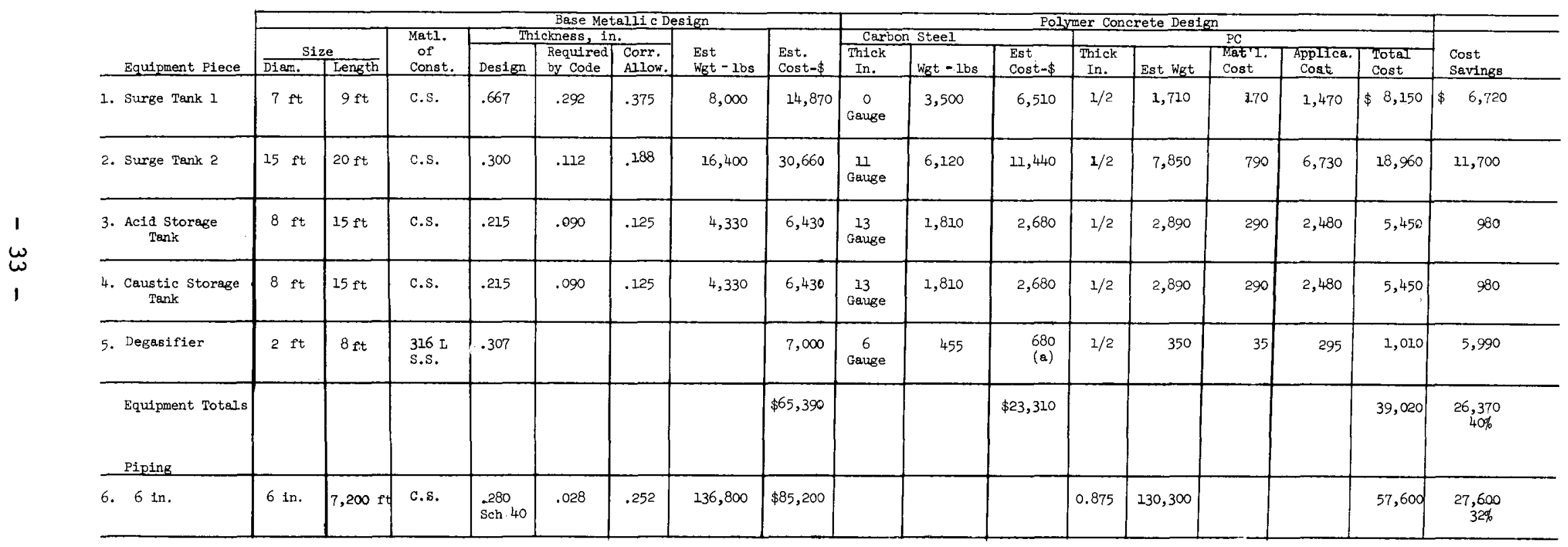

NOTES:

B. Based on Assumed Unit Cost of $\$ 1.50 / 1 b$

SI Unit Conversions

I f $=0.3048$ mi
in. $=0.0254$

$\mathrm{I} \mathrm{Ib}=0.45 \mathrm{~kg}$ 
minutes. The vessel is constructed of carbon steel, with a corrosion allowance of $3 / 8 \mathrm{in}$. (9.5 mm) and dimensions of 9 ft $(2.7 \mathrm{~m})$ in length by $7 \mathrm{ft}(2.1 \mathrm{~m})$ in diameter. The brine is transferred via pump 1 , a carbon steel pump capable of $550 \mathrm{gpm}$ (2082 1/min) through a 6 in. (152 mm) Sch 40 carbon steel pipe to the pretreatment system.

The pretreatment system is shown in Figure 3 in the dashed-in area. This pretreatment is exactly analogous to the system described in the preceding sugar beet section, with only flows and vessel sizes, changing. Due to the characteristics of the brine used, this pretreatment system is considered optional for the barley malting system. However, we have included it in this analysis since it is a potential application for non-metallic materials.

The brine, pumped at 550 gallons per minute (2082 $1 / \mathrm{min})$, is mixed with a 50 percent sulfuric acid solution in a titanium static mixer. The flow rate of sulfuric acid solution is less than $0.5 \mathrm{gpm}(1.9 \mathrm{l} / \mathrm{min})$. The $\mathrm{CO}_{2}$ gas and other noncondensables are stripped from the brine in a stainless steel degassifier (packed column) with dimensions of $2 \mathrm{ft}(.61 \mathrm{~m})$ diameter by $8 \mathrm{ft}(2.4 \mathrm{~m})$ long with $3 \mathrm{ft}$ $(0.91 \mathrm{~m})$ of ceramic saddle packing. A conservative steam flash of $2.39 \times 10^{3} \mathrm{lb} / \mathrm{hr}(1084 \mathrm{~kg} / \mathrm{hr}$ ) (1 weight percent of the feed brine) is necessary to strip the carbon dioxide and other noncondensables from the brine. The brine is then neutralized by a 50 percent caustic solution. The caustic and acid tanks are both constructed of carbon steel with a corrosion allowance of $1 / 8 \mathrm{in.}(3.2 \mathrm{~mm})$ and they have a capacity of $6,000 \mathrm{gal}(22,710$ 1) which is equivalent to about 20 days of storage. The brine then passes through the air heater tubes. The cooled brine is then collected in Surge Tank 2 prior to transfer to the injection well. Surge 
Tank 2 is designed to operate at atmospheric pressure and $150^{\circ} \mathrm{F}\left(66^{\circ} \mathrm{C}\right)$, with a capacity of 26,000 gallons $(98,4101)$ which is equivalent to 20 minutes of storage. It is constructed of carbon steel with a $3 / 16$ in. $(4.8 \mathrm{~mm})$ corrosion allowance and has the overall dimensions of $20 \mathrm{ft}(6.1 \mathrm{~m})$ long by $15 \mathrm{ft}(4.6 \mathrm{~m})$ in diameter. The brine is then pumped through a cartridge type in-line filter unit on its way to the injection well.

Pipelines from the wells to the plant are designed for an operating pressure of $100 \mathrm{psig}(690 \mathrm{kPa})$ and $300^{\circ} \mathrm{F}$ $\left(149^{\circ} \mathrm{C}\right)$. The pipeline required for transferring geothermal brine to and from the barley malting plant is a 6 in. (152 $\mathrm{mm}$ ) Sch 40 carbon steel line. For the sake of presenting definite numbers for this study, it is assumed that the wells are located $3,000 \mathrm{ft}(914 \mathrm{~m})$ from the plant. Within the plant itself, it is assumed that $1,200 \mathrm{ft}(366 \mathrm{~m})$ of 6 in. (152 mm) pipe are needed.

Polymer Concrete (PC) Design: The polymer concrete design developed by BRISC is the same as the base design described in the previous section with the following changes:

1. The thickness of all carbon steel vessels and tanks has been reduced by the amount of the specified (1) corrosion allowance. A $1 / 2 \mathrm{in.}(12.7 \mathrm{~mm})$ thick lining of PC has been added to the inside surface of these vessels and tanks.

2. The 316 stainless steel degassifier vessel has been replaced by a carbon steel vessel lined with a $1 / 2$ in. $(12.7 \mathrm{~mm})$ thick layer of PC.

3. The $6 \mathrm{in}$. (152 mm) Sch 40 carbon steel pipe has been replaced with solid PC pipe. Such pipes have already been made at the BNL and are being tested in geothermal brine applications. (6) 
As with the sugar beet analysis described earlier, BRISC has used the design data (thicknesses, corrosion allowances, etc.) and cost estimates from Reference 1 for purposes of developing incremental costs for the base design versus the PC design. However, this is not intended to imply our agreement with the data presented in Reference 1. Thicknesses of carbon steel vessels have been obtained by the same method described in the earlier section on the sugar beet plant. Table 5 compares the equipment and piping specifications for the PC design with those for the base design.

Epoxy Coated Design: As in the case of the sugar beet plant, the Coury and Associates report (1) also contains data for a design in which an epoxy coating is used on the carbon steel vessels. Again, the corrosion allowance was reduced to $.025 \mathrm{in}$. on the coated units. In addition, BRISC has substituted a 6 in. (152 mm) diameter solid PC pipe for the same size carbon steel pipe specified in the referenced report. All other aspects of the design are identical to the base case design.

Table 6 compares the equipment and piping specifications for the epoxy coated design with those for the base design.

District Heating System - Klamath Falls, Oregon

Base Design: The city of Klamath Falls, Oregon is in the process of developing a geothermal heating district system. Initially, (Phase I) fourteen city, county, state and federal office buildings in the downtown area will be served by the system. During the next phase this system will be greatly expanded by including several commercial buildings located in the same area. LLC Geothermal Consultants have developed a conceptual design for the initial 
TABLE 6. BARLEY MALTING PROCESS

Design and Cost Comparison Base Metallic Design Versus Epoxy Coated Design

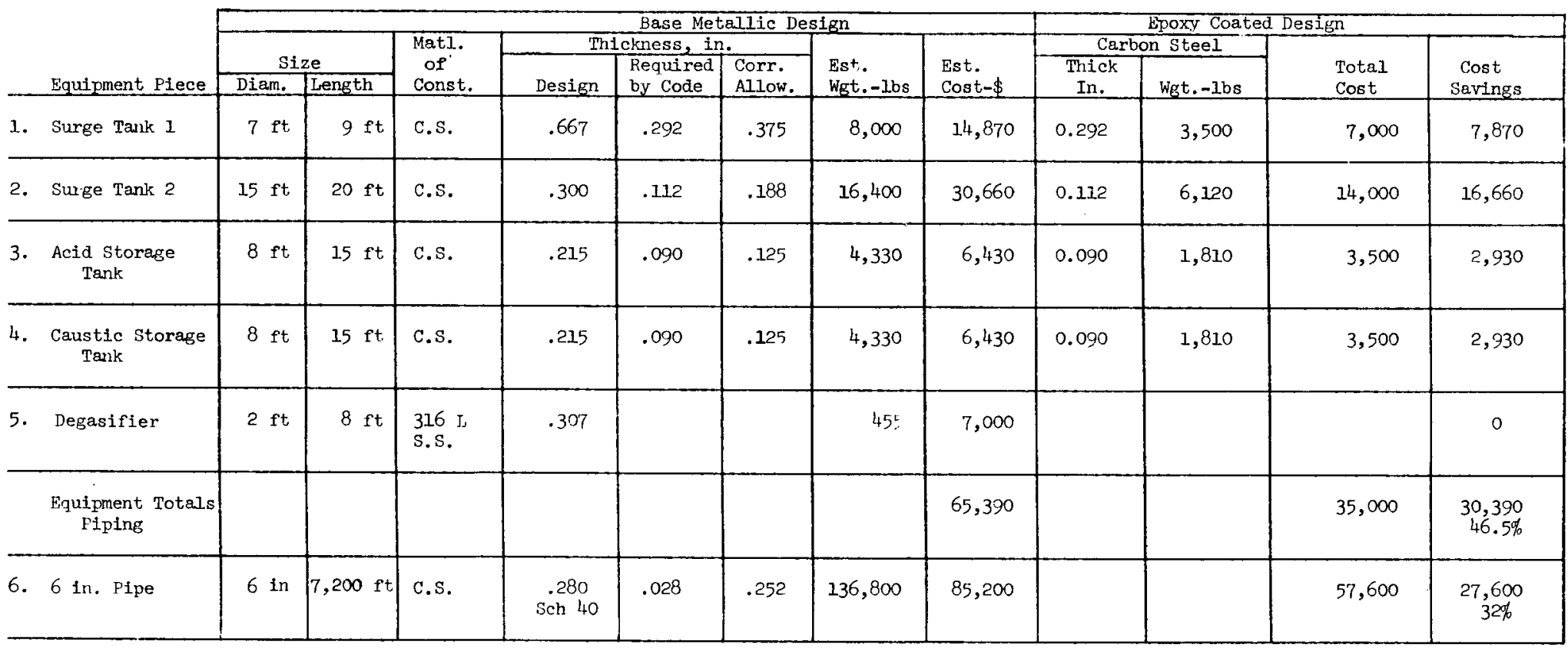

SI Un:it Conversions

It $=0.3048 \mathrm{~m}$

$\begin{array}{ll}1 \mathrm{n} & =0.0254 \mathrm{~m} \\ 1 \mathrm{~b} & =0.454 \mathrm{~kg}\end{array}$ 
fourteen-building system. In this study the following four different piping systems were considered in detail:

Steel pipe in concrete trench

Steel pipe in protective covering

Fiberglass reinforced plastic pipe (FRP)

Asbestos cement pipe (AC)

No corrosion allowances were assumed in any of these four designs because the geothermal wells under consideration produce noncorrosive water and the exterior of the pipes will be protected from possible corrosive soil conditions by a watertight jacket around the insulation or by a concrete trench.

From the production wells geothermal water at a temperature of up to $225^{\circ} \mathrm{F}\left(107^{\circ} \mathrm{C}\right)$ will be pumped through a 16 in. $(406 \mathrm{~mm})$ insulated pipe to the central heat exchangers which are located $4060 \mathrm{ft}(1237 \mathrm{~m}$ ) from the well (see Figure 5). Upon completion of the wells and subsequent well testing, it will be determined if it is necessary to install a return line back to the production field for reinjection. The first choice is to use an existing well near the planned heat exchanger building for the initial fourteen government buildings' design. A 16 in. (406 mm) insulated pipe is necessary to supply the entire commerical business district, including the fourteen government buildings at a design capacity of $6750 \mathrm{gpm}(25,549 \mathrm{l} / \mathrm{min})$ and a velocity of 10.4 $\mathrm{ft} / \mathrm{sec}(3.2 \mathrm{~m} / \mathrm{sec})$ at peak load.

The secondary pipe system delivers treated city water at $180^{\circ} \mathrm{F}\left(82^{\circ} \mathrm{C}\right)$ from the heat exchangers to the government buildings and returns the cooled water to the heat exchangers to be reheated. The insulated supply and return lines are both buried in the same trench. They are designed to supply a total of $1360 \mathrm{gpm}(5148 \mathrm{l} / \mathrm{min})$ to the fourteen buildings in the Phase I district. The supply and return legs of the secondary system utilize a combined total of $4340 \mathrm{ft}$ (1373 $\mathrm{m}$ ) 


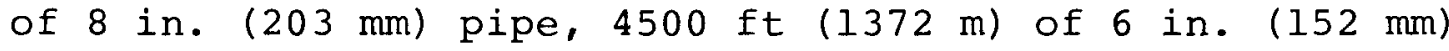
pipe and $2720 \mathrm{ft}(829 \mathrm{~m})$ of $3 \mathrm{in}$. $(76 \mathrm{~mm})$ pipe. Both the primary and secondary systems will be located in developed residential and commercial areas, requiring underground distribution. The design of this type system must:

Resist external and interior corrosion;

Withstand added structural load or motion due to settling of disturbed soil and traffic moving over the pipe at street crossings and in alleys;

Keep heat loss to a minimum during low load conditions;

Provide a resistance to fatigue and thermal stress failures due to temperature variations;

Be cost effective.

A discussion follows on the four types of piping systems considered for this project by LLC:

$\frac{\text { Case } 1-\text { Steel Pipe in a Concrete Trench }}{\left(350^{\circ} \mathrm{F}\left[177^{\circ} \mathrm{C}\right] \text { Maximum Temperature) }\right.}$

This type system consists of a poured-in-place or precast reinforced concrete box or trench with removable concrete lids, which can be used for sidewalks, and can be removed to provide access for maintenance or installation of future pipes. The insulated carrier pipes are supported within the box on steel rollers which are imbedded into the concrete (see Figure 6). After installation, the pipes are insulated with preformed fiberglass or rock wool. Allowance for expansion is primarily by bellows-type expansion joints which are dual acting with an anchor between the bellows. The entire assembly is placed on a gravel bed which contains drain tile. The concrete trench is extremely durable, can be used for other utilities and can be constructed by local contractors. Its main drawback is that it is expensive to construct compared to other type systems. 
This type of system is popular in European district heating systems and in Iceland, where extensive geothermal district heating systems have been in existence for many years. Concrete trenches are usually used for pipe 10 in. $(254 \mathrm{~mm})$ in diameter or larger.

Case 2 - Steel Pipe Directly Buried

$\left(250^{\circ} \mathrm{F}\left[121^{\circ} \mathrm{C}\right]\right.$ Maximum Temperature)

A single carrier pipe is enclosed in polyurethane insulation with a tight jacket of fiberglass reinforced plastic (FRP) or PVC. Pipe joints are welded, insulated and sealed with a joint kit. The pipe is placed in a bed of sand within the trench (see Figure 7). Manholes are constructed between anchors to house the expansion bellows and insulation around elbows is oversized to allow expansion. There are usually eight segments or $320 \mathrm{ft}(97.5 \mathrm{~m})$ between an anchor and manhole. The manholes are constructed of reinforced concrete with drain provisions. Although costs per lineal foot are comparable to nonmetallic pipe, the added cost for manholes and expansion bellows makes it more expensive.

Case 3 - Fiberglass Reinforced Plastic Pipe (FRP) $\left(210^{\circ} \mathrm{F}\left[99^{\circ} \mathrm{C}\right]\right.$ Maximum Temperature)

A single FRP carrier pipe is enclosed in polyurethane insulation with a tight jacket of FRP or PVC. The pipe is either epoxy or polyester plastic reinforced with filament wound fiberglass. The epoxy type can handle temperatures up to $350^{\circ} \mathrm{F}\left(177^{\circ} \mathrm{C}\right)$ and has a low coefficient of roughness, $\mathrm{C}=140$. The coefficient of linear expansion is relatively low compared to steel. However, a polyester resin pipe of this type failed recently when it pulled apart, mainly at joints, when the pipe cooled. Therefore, a slipring-type coupling may be more desirable than an epoxy cemented joint. The pipe is placed in a bed of sand in the trench according to Figure 7 . 


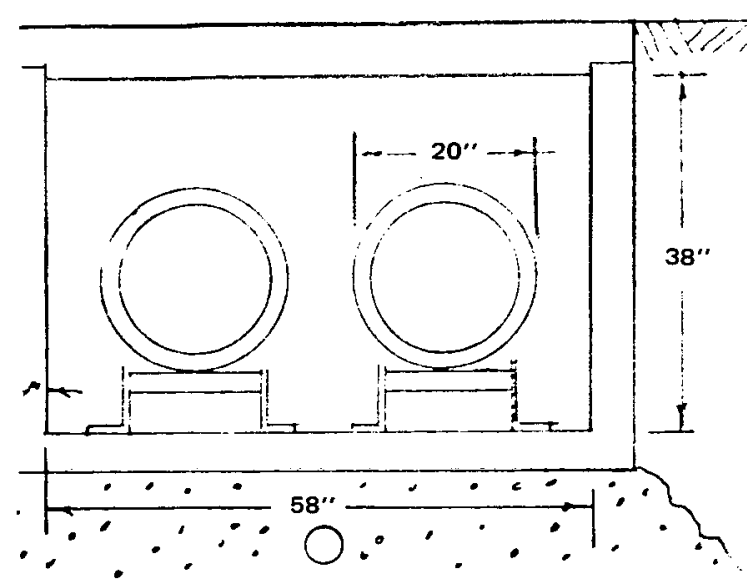

Antr?

Figure 6. District Heating System; Concrete Trench (Ref. 2)
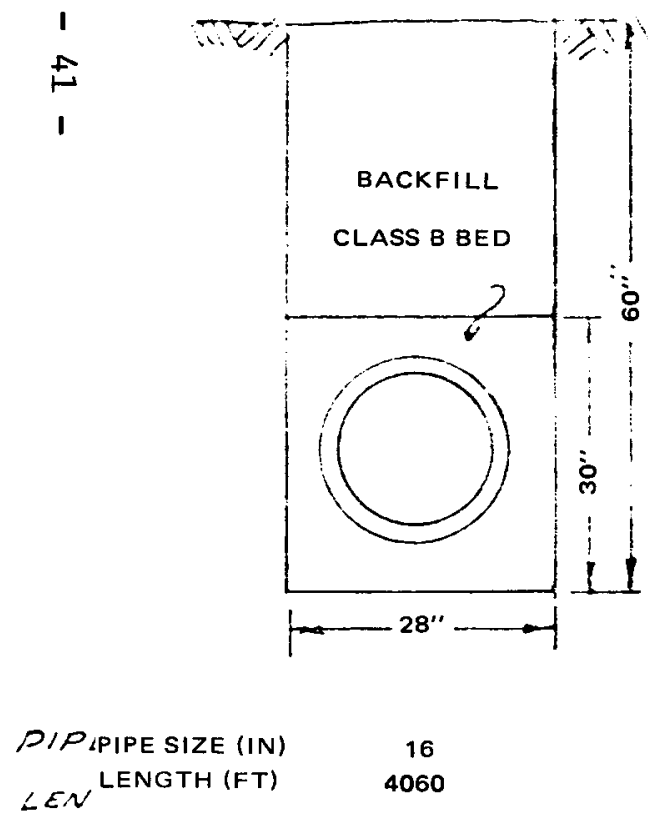
LN LENGTH (FT)
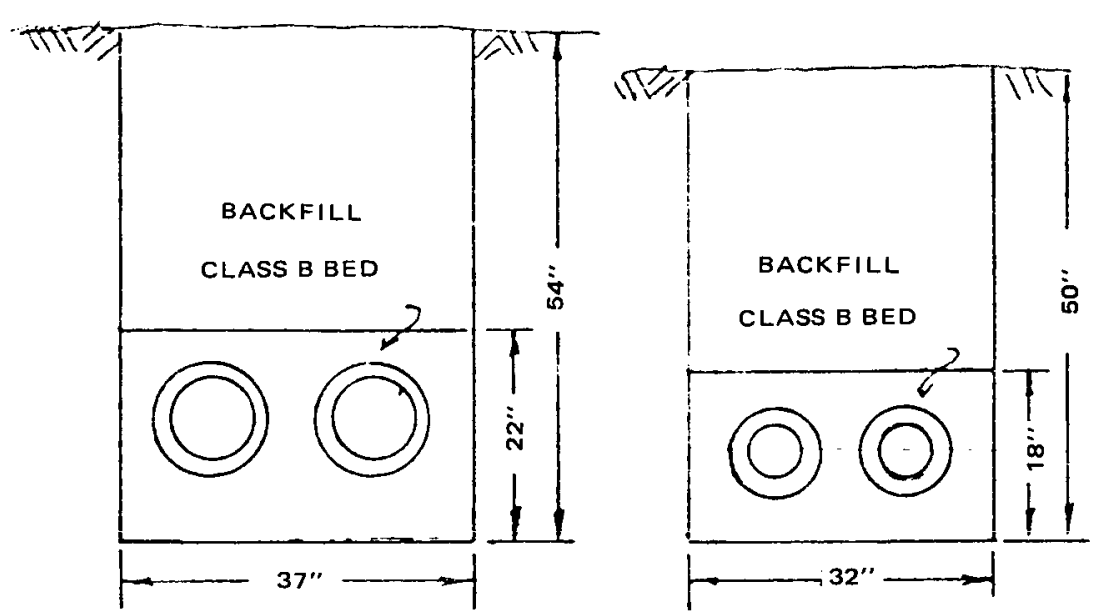

8
2170
6

2250

\begin{tabular}{|c|c|}
\hline \multicolumn{2}{|c|}{ PIPE SIZE } \\
\hline 10 & $O D$ \\
\hline $16^{\prime \prime}$ & $20^{\prime \prime}$ \\
\hline $8^{\prime \prime}$ & $12^{\prime \prime}$ \\
\hline $6^{\prime \prime}$ & $10^{\prime \prime}$ \\
\hline
\end{tabular}

CONCRETE TRENCH

INSIDE DIMEN.

$58^{\prime \prime} \times 38^{\prime \prime}$

$42^{\prime \prime} \times 30^{\prime \prime \prime}$

$38^{\prime \prime} \times 28^{\prime \prime}$
LENGTH

4060'

2170 $2250^{\prime}$

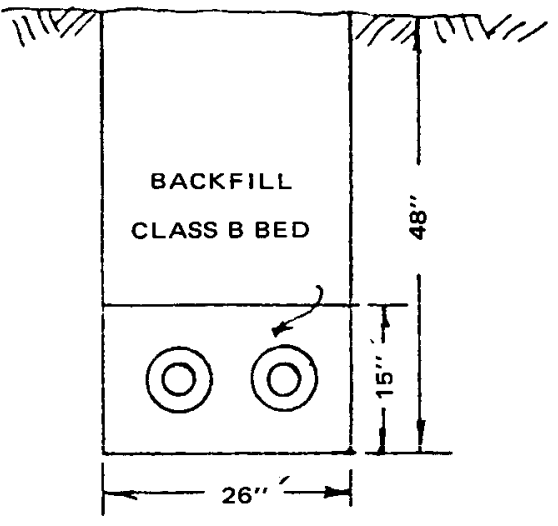

3
1360
TOTALS 9840

Figure 7. District Heating System; Concrete Trench (Ref. 2) 
The main advantages of this type of piping system is the resistance to corrosion and the low roughness coefficient.

Case 4 - Asbestos Cement Pipe (AC)

$\left(210^{\circ} \mathrm{F} \quad\left[99^{\circ} \mathrm{C}\right]\right.$ Maximum Temperature)

This type pipe has an epoxy lined AC carrier pipe, polyurethane insulation and an AC jacket. The temperature limit of this pipe is $210^{\circ} \mathrm{F}\left(99^{\circ} \mathrm{C}\right)$ because of the epoxy lining. Thus, in order for it to be used for the $225^{\circ} \mathrm{F}$ $\left(107^{\circ} \mathrm{C}\right)$ supply line, special provisions must be made. For instance, the line may be broken (flashed) to atmosphere at the well head. Another alternative would be to use uninsulated AC for the $16 \mathrm{in.} \mathrm{(406} \mathrm{mm)} \mathrm{supply} \mathrm{line} \mathrm{in} \mathrm{the} \mathrm{winter}$ when the demand is large and velocities are high. A second

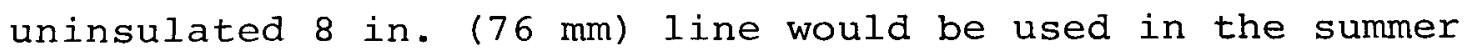
months to minimize temperature drops when the load is low. AC pipe may fracture when a temperature change (cooling) occurs. Expansion occurs in the slipring-type joints and proper bedding and backfill are important (see Figure 7). The main advantage of $\mathrm{AC}$ pipe is the resistance to corrosion. Also, the slipring joints are quick to assemble and eliminate the need for expensive expansion joints and manholes.

Polymer Concrete (PC) Design: In this study BRISC has developed two alternate pipe designs utilizing polymer concrete.

Case 5 - Directly Buried (PC) Carrier Pipe with PC
Jacket

This first design consists of a solid PC carrier pipe, polyurethane insulation and a solid PC jacket directly buried in a trench with proper bedding and backfill in accordance with Figures 5 and 7 . This design is basically identical to the AC design (Case 4) with the exception that 
PC material has been substituted for all asbestos cement material. Pipe wall thicknesses have been modified for PC in accordance with the properties of PC material. No effort has been made in this study to evaluate or change the design described in Reference 2 in terms of sizing, arrangement, etc.

\section{Case 6 - PC Pipe in Concrete Trench}

The second alternative design developed by BRISC consists of a solid PC pipe with polyurethane insulation enclosed in a concrete box. The design is the same as case 1 above except for the substitutuion of PC pipe for the carbon steel pipe. 


\section{PROCEDURES}

Sugar Beet Refining and Barley Malting Plants

All design and cost data for the base metallic designs and for the epoxy coated designs were taken directly from a report by Coury and Associates, Inc. (1) with one exception. In the epoxy coated design, the carbon steel pipe specified in the referenced report was replaced by BRISC with a correspondingly sized solid polymer concrete pipe. The method used to cost this pipe is the same as that described later for the polymer concrete design.

For the polymer concrete (PC) designs the basic approach used to determine the cost benefits (positive or negative) was similar to that used in an earlier study performed by BRISC for BNL concerning geothermal electric power plants.

BRISC has not attempted to duplicate coury's effort in the design and cost estimation of the plants. Rather, we have estimated the incremental costs which would be incurred by substituting PC for materials used by coury in their base design. No effort has been made to estimate the cost of erection, installation and insulation of the equipment; thus, the assumption that these costs would be similar for both designs is implicit in any conclusion drawn. Further, it has been assumed that there would not be any appreciable savings in fabrication labor costs due to the thinner carbon steel shells used in the PC designs.

The minimum required thickness for each vessel and pipe has been calculated using methods described in the previous section (Description of Plants). The cost estimates are based on the next thicker, commercially available plate. To this cost was added the cost of PC and its cost of application. For those parts for which Coury used materials other than carbon steel, the minimum thickness for the substitute 
carbon steel vessel has been calculated by BRISC using ASME Code Section VIII procedures.

The weight of each vessel and tank was calculated from diameter, length and thickness data presented for the base design in Reference 1. This weight was then divided into the costs reported in Reference 1 for the respective vessel or tank. The resulting unit cost ( $\$ / I b)$ for carbon steel was used to determine the cost of the corresponding vessel with a thinner shell in the PC design. Since costs in the reference are based on 1977-1978 prices, no escalation adjustment has been made. In general, the unit costs vary from vessel to vessel and range from $\$ 0.56 / 1 \mathrm{~b}(\$ 1.23 / \mathrm{kg})$ to $\$ 1.87 / 1 \mathrm{~b}(\$ 4.12 / \mathrm{kg})$ for the carbon steel vessels.

In this study, the estimated cost of PC linings on vessels consisted of two components. The first was the material cost for bulk quantities of PC. This was estimated to be $\$ 0.10 / 1 \mathrm{~b}(\$ .22 / \mathrm{kg})$ based on data obtained from the literature. (9) The second component of cost was for application of the PC to the surface. This was estimated to be $\$ 5 / \mathrm{ft}^{2}\left(\$ 53.82 / \mathrm{m}^{2}\right)$ based on past experience in the purchase of concrete linings. (8) In applying refractory cement or similar linings to carbon steel shells, it is common industrial practice to weld "Nelson studs" or similar stand-off devices to the shell and then to weld a supporting expanded metal mesh to them. Following this, the concrete is applied by guniting and/or trowelling. We have assumed that a similar procedure would be used in applying PC. The assumed application cost of $\$ 5.00$ per square foot $\left(\$ 53.82 / \mathrm{m}^{2}\right)$ includes the cost of the support materials and their application. Our estimates contain some conservatism because we 
have added the material cost of the PC but have not backed out the cost of the refractory cement.

Table 7 contains the unit costs (\$/ft) for carbon steel piping in the base design. This data was extracted directly from the Coury report. (1) Delivered costs for the uninsulated polymer concrete pipe was estimated by procedures described below for the district heating system. For the 6 in. (152 mm) diameter PC pipe, a total cost of $\$ 8 / \mathrm{ft}(\$ 26.25 / \mathrm{m})$ was used which consists of a cost of $\$ 2 / \mathrm{ft}(\$ 6.56 / \mathrm{m})$ for the bare pipe plus $\$ 6 /$ ft $(\$ 19.68 / \mathrm{m})$ for insulation. (10) Similarly, for the $20 \mathrm{in.}(508 \mathrm{~mm})$ PC pipe, a total cost of $\$ 24 / \mathrm{ft}$ $(\$ 78.74 / \mathrm{m})$ was used which consists of $\$ 10 / \mathrm{ft}(\$ 32.80 / \mathrm{m})$ for the bare pipe plus $\$ 14 /$ ft $(\$ 45.93 / \mathrm{m})$ for the insulation.

District Heating system

Table 8 shows the district heating piping system capital costs for cases $1-6$ as described in section VI. The costs for cases 1-4 were all obtained directly from a report by LIC Geothermal consultants. (2) The methodology used by BRISC to develop the costs for cases 5 and 6 is described in the following paragraphs.

The basic approach in estimating the cost of a directly buried solid PC piping system for district heating was to determine the incremental cost for replacing the $A C$ material in the Case 4 design with PC. AC pipe dimensional and cost data were obtained from Johns Manville, the manufacturer of asbestos cement pipe. These data are presented in Table 9. The top section of Table 9 contains data concerning plain AC (transite) pipe without insulation and without a jacket. This enables us to determine the unit cost of the AC piping material excluding insulating material, assembly and couplings. Overall cost for the AC material in pipe form 
TABLE 7

PIPE UNIT COSTS (1)

Nominal Pipe Diameter (in.)

6

Temperature $\left({ }^{\circ} \mathrm{F}\right)$

Pressure (psig)

Wall Thickness (in.)

Corrosion Allowance (in.) ${ }^{1}$

$\operatorname{Sch}$ No.

Material Costs, Pipe and Insulation ${ }^{2}$ per ft (\$)

Installation cost per ft (\$)

Installed Pipe costs per ft $(\$)^{3}$

300

100

.280

.254

40

12

20

32
16

20

300

100

100

.375

.375

.308

.288

30

20

31.

38

46

56

77

94

1. The corrosion allowance differs slightly for each case, so that standard commercial pipe schedules can be used.

2. These costs, for carbon steel pipe, are based on vendor estimates.

3. Costs for above ground pipe installations.

\section{SI Unit Conversions}

$$
\begin{aligned}
& 1 \mathrm{ft}=0.3048 \mathrm{~m} \\
& 1 \mathrm{in}=0.0254 \mathrm{~m} \\
& 1 \text { psi }=6.894 \mathrm{kPa} \\
& 300^{\circ}=149^{\circ} \mathrm{C}
\end{aligned}
$$


TABLE 8.

DISTRICT HEATING SYSTEM

PIPING SYSTEMS CAPITAL COST COMPARISON

Case 1. Steel pipe in a concrete trench

$\$ 1,363,523$

Case 2. Steel pipe in a protective covering

$\$ 955,695$

Case 3. Insulated FRP pipe

$\$ 969,090$

Case 4. Insulated AC pipe

$\$ 726,394$

Case 5a. Insulated PC pipe-600 psi (4.1 MPa)

$\$ 697,781$

Case 5b. Insulated PC pipe-450 psi (3.1 MPa)

$\$ 749,126$

Case 6a. PC pipe in concrete trench-600 psi (4.1 MPa)

$\$ 1,183,436$

Case 6b. PC pipe in concrete trench-450 psi (3.1 MPa)

$\$ 1,223,077$ 
Table 9

ASBESTOS CEMENT PIPE

DESIGN AND COST DATA

\section{Carrier Pipe}

\begin{tabular}{|c|c|c|c|c|}
\hline $\begin{array}{l}\text { ID } \\
\text { Max Operating Temperature }{ }_{F}\end{array}$ & $\frac{3 \text { in. }}{200}$ & $\frac{6 \text { in }}{200}$ & $2 \frac{8 \text { in. }}{200}$ & $\frac{16 \text { in }}{226}$ \\
\hline Working pressure psi & 150 & 150 & 150 & 150 \\
\hline in. & 3.00 & 6.00 & 8.00 & 16.00 \\
\hline in. & 4.00 & 7.07 & 9.27 & 18.46 \\
\hline Wall thickness in. & 0.50 & 0.54 & 0.64 & 1.23 \\
\hline Weight $\quad 1 \mathrm{~b} / \mathrm{LF}$ & 5.3 & 11.2 & 17.35 & 62.1 \\
\hline Cost & 2.00 & 2.82 & 4.03 & 11.32 \\
\hline Cost & 37.74 & 25.2 & 23.2 & 18.2 \\
\hline
\end{tabular}

Jacket

3 in. 6 in. 8 in. 16 in.

$\begin{array}{lrcccl}\text { OD } & \text { in. } & 6.92 & 9.88 & 13.22 & 22.80 \\ \text { ID } & \text { in. } & 6.00 & 9.00 & 12.00 & 20.8 \\ \text { Weight } & \text { lb/ft } & 9.08 & 12.6 & 23.5 & 66.6 \\ \text { Cost AC jacket } \$ / L F & 2.59 & 3.17 & 4.98 & 12.08\end{array}$

Total Cost for Carrier Pipe and Jacket

Total Cost AC carrier pipe

$\begin{array}{llllll}\text { plus AC jacket } & \$ / \mathrm{LF} & 4.59 & 5.99 & 9.01 & 23.40\end{array}$

\section{SI Unit Conversions}

1. $\mathrm{ft}=0.3048 \mathrm{~m}$

1 in. $=0.0254 \mathrm{~m}$

$1 \mathrm{lb}=0.454 \mathrm{~kg}$

$1 \mathrm{lb} / \mathrm{ft}=1.49 \mathrm{~kg} / \mathrm{m}$

$1 \mathrm{psi}=6.894 \mathrm{kPa}$

$200^{\circ} \mathrm{F}=93.3^{\circ} \mathrm{C}$

$226^{\circ} \mathrm{F}=107.8^{\circ} \mathrm{C}$ 
varied from $37.7 \% / 1 \mathrm{~b}(83.1 \% / \mathrm{kg})$ for $3 \mathrm{in.}(76 \mathrm{~mm})$ pipe to $18.2 \mathrm{c} / \mathrm{lb}(40.14 / \mathrm{kg})$ for $16 \mathrm{in} .(406 \mathrm{~mm})$ diameter pipe. It was further determined that, within a range of error of $+4 \%$ and $-2 \%$, the cost of plain AC pipe could be established by using the following equation:

$$
\mathrm{c}=1.09+0.165 \mathrm{~W}
$$

where: $C=$ cost in $\$ / 1 b$.

$$
\mathrm{W}=\text { weight in } \mathrm{lb} / \mathrm{ft} \text {. }
$$

Subsequently, we applied this equation to estimate the unit cost of the $A C$ jacket in case 4. The results are shown in the middle section of Table 9. OD and ID for the jacket were obtained from the manufacturer. Weight in $\mathrm{lb} / \mathrm{ft}$ for the jacket were calculated assuming the same material density as for the carrier pipe. The total cost of AC carrier pipe and $A C$ jacket are shown in the bottom section of Table 9 .

Next, minimum wall thicknesses for the PC carrier pipe were determined for a working pressure of 150 psi (1034 $\mathrm{kPa})$. Published data on PC materials show a tensile strength of $1500 \mathrm{psi}^{(6)}(10,340 \mathrm{kPa})$ as determined with the split cylinder test. For one set of calculations we used an allowable stress of $600 \mathrm{psi}(4137 \mathrm{kPa})$. We believe this to be a reasonable approach because the ACI code philosophy on allowable stresses indicates a safety factor of 0.4 on tensile strength could be used. However, we also made a more conservative evaluation of the PC by assuming an allowable stress of only $450 \mathrm{psi}(3103 \mathrm{kPa})$. In addition, we assumed a minimum wall thickness of at least 0.5 in. (12.7 $\mathrm{mm}$ ) in all instances in order to ensure sufficient homogeneity of the wall. For calculating the OD and wall thickness we applied the following equation because we were dealing with relatively thick walls: 


$$
\mathrm{D}_{0}=\mathrm{D}_{\mathrm{i}}\left[\begin{array}{l}
\mathrm{S}+\mathrm{P} \\
\mathrm{S}-\mathrm{P}
\end{array}\right] \quad \begin{aligned}
& \text { where } \\
& \mathrm{D}_{\mathrm{O}}=\text { outside diameter } \\
& \mathrm{D}_{\mathrm{i}}=\text { inside diameter } \\
& \mathrm{S}=\begin{array}{l}
\text { allowable ten } \\
\text { sile strength }
\end{array} \\
& \mathrm{P}=\begin{array}{l}
\text { operating } \\
\text { pressure }
\end{array}
\end{aligned}
$$

Then, assuming the density of PC to be 140 pcf (2243 $\mathrm{kg} / \mathrm{m}^{3}$ ), the specific weight in lb/ft for the solid PC carrier pipe was established (see Table 10). For determining the cost of the PC carrier pipe we used a unit cost of $10 \% / 1 \mathrm{~b}(22 \% / \mathrm{kg})$ for PC based on Reference 9. In that study, the actual quantities of pipe used to establish the unit cost were based on the records of the City of Baltimore, which showed quantities and sizes of sewer pipe required each year. The referenced report did not contain enough detail to allow us to determine the cost for each diameter individually, hence only the average unit cost for a typical $\mathrm{mix}$ of $6 \mathrm{in.}(152 \mathrm{~mm})$ to $48 \mathrm{in}$. (1219 mm) diameter sewer pipe was determined. However, as indicated earlier, the information for $A C$ pipe does indicate a variation in unit cost $(\$ / 1 b)$ for different pipe diameters. A further refinement of the PC pipe cost data as a function of diameter and wall thickness for future work seems desirable. The cost data for PC carrier pipe at $10 \% / 1 b(22 \xi / \mathrm{kg})$ are presented in the top section of Table 10 .

Insulation thicknesses for AC pipe varied from $0.96 \mathrm{in}$. (24 $\mathrm{mm}$ ) to 1.36 in. $(35 \mathrm{~mm})$.

(2) In determining the ID of the PC jacket for Case 5 we assumed a constant insulation 
Table 10

POLYMER CONCRETE PIPE

DESIGN AND COST DATA

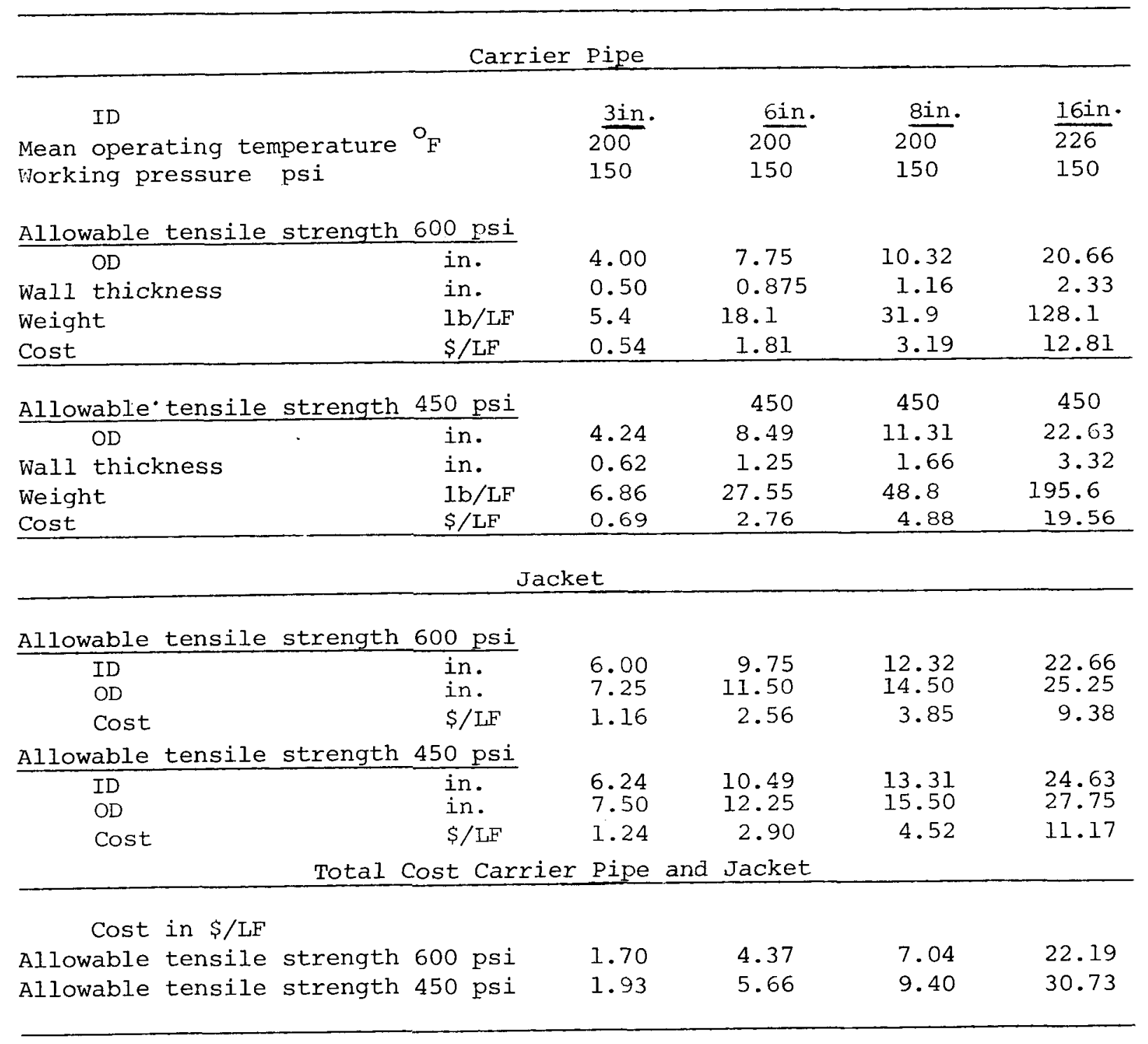

\footnotetext{
SI Unit Conversion

I ft $=0.3048 \mathrm{~m}$

1 in. $=0.0254 \mathrm{~m}$

$1 \mathrm{lb}=0.454 \mathrm{~kg}$

$1 \mathrm{lb} / \mathrm{ft}=1.49 \mathrm{~kg} / \mathrm{m}$

$1 \mathrm{psi}=6.894 \mathrm{kPa}$

$200^{\circ} \mathrm{F}=93.3^{\circ} \mathrm{C}$

$226^{\circ} \mathrm{F}=107.8^{\circ} \mathrm{C}$
} 
thickness of 1 in. $(25.4 \mathrm{~mm})$. The jacket being under a compressive load has to meet the same requirements as sewer pipe. Hence, the design and cost data for the jacket were taken directly from a report on polymer composite sewer pipe. (9) In Table 10 the unit costs of PC carrier pipe and a PC jacket are presented.

Based on data from Tables 9 and 10, Table 11 compares the cost of the PC carrier pipes and jackets (excluding insulation, assembly, couplings, trenching, etc.) to the corresponding cost for the AC pipes in Case 4. The cost for Case 5 (i.e., direct burial of PC pipe) was then determined by first subtracting the AC pipe cost from the PC pipe cost shown on Table 11. Then, the difference was added algebraically to the cost for Case 4 that is shown on Table 8 . As illustrated on Table 12, the cost for Case 6 was determined by deducting from case 5 the costs for the carrier pipe and for excavation. The costs of the concrete trench from case 1 were then added.

In the determination of operating costs, it was assumed that electrical costs for the PC designs (Cases 5 and 6) would be the same as determined by LLC Geothermal Consultants $^{(2)}$ for cases $1-4$. The annual maintenance costs for the directly buried PC design (Case 5) was determined by the following procedure. Initially, the first year's maintenance cost for the AC pipe design (Case 4) as estimated by LLC was found as a percentage of the total piping capital cost (See Table 8 ). Then, this percentage (.64\%) was used to calculate the first year's maintenance cost for the PC case. The maintenance cost for the first year was then escalated by 7 percent per year to get the corresponding annual charge for each of the 20 years of project life. Then the present worth of each year's annual maintenance 
Table 11

COST COMPARISON AC PIPE VERSUS PC PIPE

Includes Carrier Pipe and Jacket Only

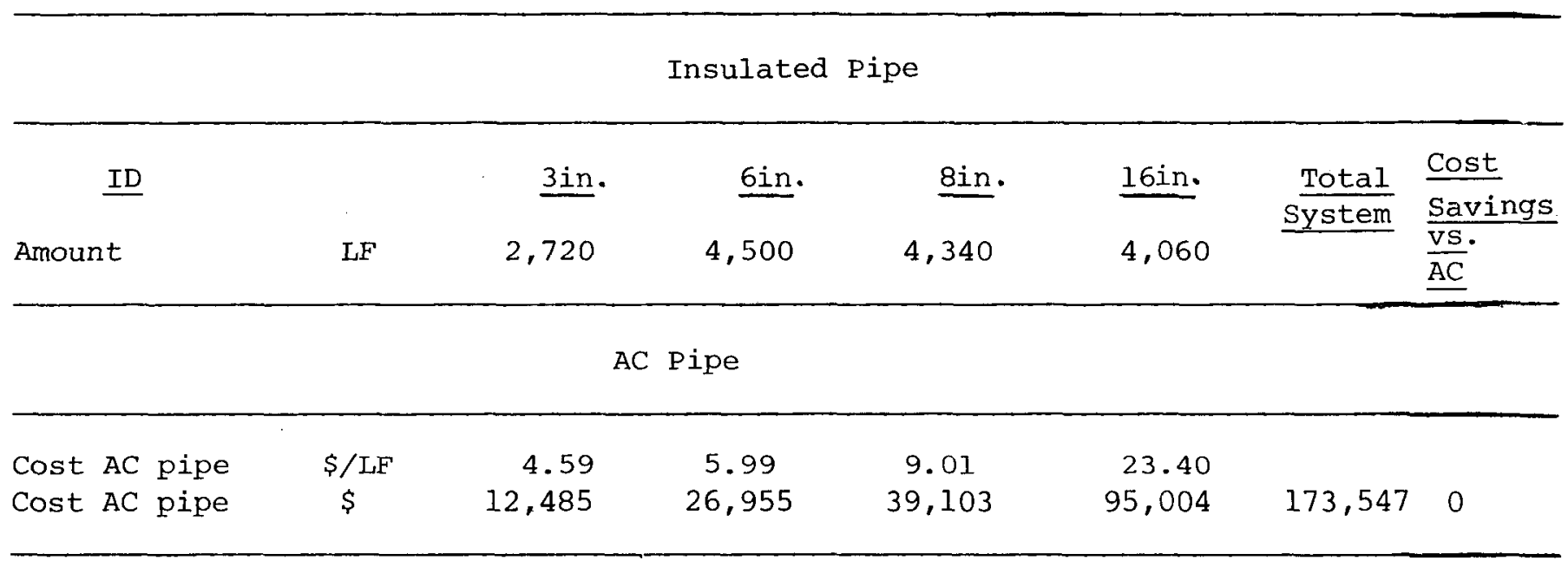

PC Pipe Allowable Stress 600 psi

\begin{tabular}{lccccccc}
\hline Cost PC pipe & $\$ / L F$ & 1.70 & 4.37 & 7.04 & 22.19 & & \\
Cost PC pipe & $\$$ & 4,624 & 19,665 & 30,554 & 90,091 & 144,934 & 28,613
\end{tabular}

PC Pipe Allowable Stress 450 psi

\begin{tabular}{|c|c|c|c|c|c|c|}
\hline Cost PC pipe & $\$ / L F$ & 1.93 & 5.66 & 9.40 & 30.73 & \\
\hline Cost PC pipe & $\$$ & 5,250 & 25,470 & 40,796 & 124,763 & $196,279-22,732$ \\
\hline
\end{tabular}

SI Unit Conversions

l ft $=0.3048 \mathrm{~m}$

l in. $=0.0254 \mathrm{~m}$

$1 \mathrm{psi}=6.894 \mathrm{kPa}$ 
Table 12

COST ESTIMATE FOR PC PIPE IN CONCRETE TRENCH (Case 6)
I - Concrete Trench Cost
$\$ 752,577$
II - Trenching Replaced by Concrete Trench
$\$ 200,610$
III - Cost of PC Jackets Not Required in Concrete Trench
Allowable tensile strength 600 psi
Allowable tensile strength 450 psi
$\$ \quad 66,312$
$\$ 78,017$
IV - Incremental Cost of Concrete Trench Versus Direct Burial = I - II - III
Allowable tensile strength 600 psi
Allowable tensile strength 450 psi
$\begin{array}{ll}\$ & 485,655 \\ \$ & 473,950\end{array}$
V - Total Case 6 System Cost $=$ Case 5 Cost +1.15 (IV) *
Allowable tensile strength 600 psi
Allowable tensile strength 450 psi
$\$ 1,783,321$
$\$ 1,828,908$

*NOTE: Factor of 1.15 accounts for engineering and inflation. 
charge was calculated based on an interest rate of $6.5 \%$. The sum of the 20 present worths was then determined and is shown on the second line of Table 20. Then, continuing to follow the procedure used by LLC, the equivalent cost (i.e., levelized annual cost) was determined by adding the present worths of the electrical operating costs and maintenance costs and then converting the total present worth to an equivalent annual annuity based on a $6.5 \%$ interest rate. It should be noted that the escalation rates used by LLC for the electrical charges differed from the 7\% used for maintenance.

The procedure for Case 6 operating costs was the same except that the percentage used to calculate the first year's cost was assumed to be half of that used for case 5 . LLC used the same ratio on the steel pipe cases (i.e., Cases 1 and 2 ) on the basis that the access afforded by the concrete trench would reduce maintenance costs.

The economic criteria and methodology used to determine energy costs for the district heating system differ from those used for the sugar beet and barley malting plants discussed earlier. For each process, BRISC used the same approach as the authors of the corresponding reports $(1,2)$ to avoid the use of assumptions which might favor the nonmetallic material cases. 


\section{RESULTS OF STUDY}

Sugar Beet Refining

The results of the incremental capital cost analysis for the polymer concrete (PC) and epoxy coated designs are shown on Tables 2 and 3 respectively. Relative to the base metallic design, the delivered cost of all vessels in the battery limits geothermal fluid system would be reduced by 30 percent $(\$ 85,400$ out of $\$ 283,030)$ through the utilization of the polymer concrete design. Similarly, for the epoxy coated design, a total savings of 47 percent $(\$ 134,110$ out of $\$ 283,030)$ could be obtained on the cost of vessels. Note that installation, erection, and insulation costs are not included in this comparison of delivered costs.

In terms of piping, the use of insulated solid PC pipe in lieu of carbon steel with corrosion allowances would result in a savings of 39 percent $(\$ 110,200$ out of $\$ 283,000)$. Again, installation costs are not considered in this comparison.

A cursory review of the cost data indicated that no savings would be achieved by utilizing a $1 / 2 \mathrm{in.} \mathrm{(1.2.7} \mathrm{mm}$ ) thick lining of $\mathrm{PC}$ on the inside of the steel pipe instead of the corrosion allowance specificed in the reference. (1)

This is due to the fact that the minimum commercially available thickness for $16 \mathrm{in.} \mathrm{(406} \mathrm{mm)} \mathrm{pipe} \mathrm{is} 1 / 4 \mathrm{in}$. $(0.4 \mathrm{~mm})$. Therefore, while the required thickness without corrosion allowance is only $.083 \mathrm{in.}(2.1 \mathrm{~mm})$ the PC design can only take credit for a $1 / 8 \mathrm{in}$. $(3.2 \mathrm{~mm})$ reduction in wall thickness relative to the base design. This credit is not enough to cover the cost of lining the pipe with PC.

Table 13 compares the total geothermal system (including wells, pumps, controls, etc.) capital costs for the base sugar beet plant design with those for the PC design and the epoxy coated design. In this case, the capital costs shown 
Table 13

SUGAR BEET PLANT - CAPITAL COST COMPARISON

Bases:

-Efficiency of Fossil - Fuel Plant

(\% Steam on Beets)

-Brine Consumption of Geothermal Plant $\left(10^{6} \mathrm{lb} / \mathrm{hr}\right)$

-No. of Production Wells

-No. of Brine Disposal Wells

-No. of Spare Wells (1 Production, 1 Disposal)

-Heat Transfer Surface Area (sq ft)

-For Geothermal Plant

-For Fossil-Fuel Plant

-Incremental Geothermal Surface Area (sq ft)

44

2.8

6

3

2

161,800

76,100

85,700
Capital Costs: $(\$ 1,000)$

-We11 cost

-Piping and Pumps

-Incremental Surface Area Costs*

-Additional Equipment Costs

-Flash \& Surge Tanks, Pretreatment systems

-Air Compressor (For Beet Knife Cleaning)

-Vacuum Pump (To Replace Steam Jet Ejectors)

-Net Incremental Capital Costs for a
Base Design (with corr. allowances on pipe and vessels)

$\begin{array}{r}7,150 \\ 760 \\ 1,610 \\ 459 \\ 50 \\ 68 \\ \hline\end{array}$

10,097
Epoxy

Lined

Polymer

Concrete Design

7,150 650

1,610

374

50

68

Vessels and $\mathrm{PC}$ Pipe

7,150 650

1,610

325

50

68

9,902

9,853

*Costs: Evaporators $\left(\$ 12.50 / \mathrm{ft}^{2}\right)$; Vacuum Pans $\left(\$ 105 / \mathrm{ft}^{3}\right)$; Heaters $\left(\$ 15 / f t^{2}\right)$.

$\underline{\text { SI Unit Conversions }}$

$1 \mathrm{lb}=0.454 \mathrm{~kg}$

$1 \mathrm{ft}^{2}=0.0929 \mathrm{~m}^{2}$

$1 \mathrm{ft}=0.0283 \mathrm{~m}^{3}$ 
are really the incremental costs of a geothermal plant versus a conventional fossil fuel plant. Using data from Table 13, the net savings in energy costs $\left(\$ / 10^{6}\right.$ Btu) associated with the use of polymer concrete and epoxy coatings were determined and are shown on Table 14. As indicated, the savings are $\$ .05 / 10^{6} \mathrm{Btu}\left(\$ .047 / 10^{9} \mathrm{~J}\right)$ or $1.7 \%$ for the PC design and $\$ 0.06 / 10^{6} \mathrm{Btu}\left(\$ .057 / 10^{9} \mathrm{~J}\right)$ or $2.1 \%$ for the epoxy coated design.

Barley Malting Process

Tables 5 and 6 show the results of the incremental cost analysis for the polymer concrete and epoxy coated designs, respectively. Compared to the base metallic design, the total delivered cost of all vessels in the battery limits geothermal fluid system can be reduced by 40 percent $(\$ 26,370$ out of $\$ 65,390)$ through utilization of the polymer concrete design. Similarly, by using the epoxy coated design, the total delivered cost of all vessels could be reduced by 46 percent $(\$ 30,390$ out of $\$ 65,390)$.

Concerning the piping, Tables 5 and 6 show that the substitution of solid PC pipe for $6 \mathrm{in}$. (152 mm) Sch 40 carbon steel pipe would result in a cost savings of $32 \%$ $(\$ 27,600$ out of $\$ 85,200)$. Note that installation costs are considered equal for both types of pipe in this analysis.

A comparison of total geothermal system (including wells, controls, pumps, etc.) capital costs for the barley malting plant base design versus the polymer concrete and epoxy coated designs is shown on Table 15. Based on this data, Table 16 shows that the estimated net savings in energy costs associated with the use of polymer concrete would be $\$ 0.06 / 10^{6}$ Btu $\left(\$ 0.057 / 10^{9} \mathrm{~J}\right)$ or $2.2 \%$. Similarly, the savings associated with the use of the epoxy coated design would be $\$ .05 / 10^{6}$ Btu $\left(\$ .047 / 10^{9} \mathrm{~J}\right)$ or $1.8 \%$. 
Table 14

SUGAR BEET PLANT - ENERGY COST COMPARISON

\section{Basis:}

Replacement of equivalent fuel requirement for a fossil fuel fired beet sugar factory.

A. Energy Usage in Fossil Fuel Plant

1. Plant Efficiency (\% Steam on Beets) 44

2. Energy to Process $\left(10^{6} \mathrm{Btu} / \mathrm{hr}\right)$

3. Boiler Efficiency

4. Total Fossil Fuel Requirement $\left(10^{6} \mathrm{Btu} / \mathrm{hr}\right)$

B. Costs of Geothermal System

\begin{tabular}{|c|c|c|}
\hline $\begin{array}{l}\text { Base Design } \\
\text { (with corr. } \\
\text { allowance) }\end{array}$ & $\begin{array}{l}\text { Polymer } \\
\text { Concrete } \\
\text { Design } \\
\end{array}$ & $\begin{array}{l}\text { Epoxy } \\
\text { Lined } \\
\text { Design }\end{array}$ \\
\hline 1,515 & 1,485 & 1,478 \\
\hline 526.0 & 515.6 & 513.2 \\
\hline 70 & 70 & 70 \\
\hline 6 & 6 & 6 \\
\hline 602 & 591.6 & 589.2 \\
\hline
\end{tabular}

1. Annual Amortization $(\$ 1,000)$ *

2. Hourly Amortization $(\$ / \mathrm{hr})$ **

3. Brine Treatment $(\$ / \mathrm{hr}) * * *$

4. Additional Electrical ( $\$ / \mathrm{hr}$ )

5. Total Geothermal Hourly Costs $(\$ / h r)$

\begin{tabular}{c}
$\begin{array}{c}\text { Base Desig } \\
\text { (with corr } \\
\text { allowance) }\end{array}$ \\
1,515 \\
526.0 \\
70 \\
6 \\
\hline 602
\end{tabular}

Cost of Geothermal Systems

B5 $\div$ A4 (\$ per $10^{6}$ Btu replaced)

2.88

2.83

2.82

* 15\% of Capital Charges (see Table 13)

**120-day processing campaign; 24 hours per day

$* \star * \$ 25$ per million pounds

$$
\begin{array}{ll}
\text { SI Unit } & \text { Conversions } \\
1 \mathrm{1b}= & 0.454 \mathrm{~kg} \\
1 \mathrm{Btu} & =1.0546 \mathrm{~kJ} \\
10^{6} \mathrm{Btu} & =1.0546 \mathrm{GJ}
\end{array}
$$


Table 15

BARLEY MALTING PLANT - CAPITAL COST COMPARISON

\begin{tabular}{|c|c|c|c|}
\hline \multicolumn{2}{|l|}{$\begin{array}{l}\text { Geothermal Brine } \\
\text { Temperature }\left({ }^{\circ} \mathrm{F}\right)\end{array}$} & \multicolumn{2}{|l|}{260} \\
\hline Brine Flow $(1,000$ lb/hour $)$ & & 239 & \\
\hline No. of Wells & & 4 & \\
\hline Capital Cost: $\quad(\$ 1,000)$ & $\begin{array}{l}\text { Base Design } \\
\text { (with corr. } \\
\text { allowance) } \\
\end{array}$ & $\begin{array}{l}\text { Polymer } \\
\text { Concrete } \\
\text { Design } \\
\end{array}$ & $\begin{array}{l}\text { Epoxy Lined } \\
\text { Vessels } \\
\text { and PC Pipe }\end{array}$ \\
\hline Wells & 2,200 & 2,200 & 2,200 \\
\hline Lines, Pumps and Surge Vessels & 363.4 & 309.4 & 305.4 \\
\hline Air Heater & 450 & 450 & 450 \\
\hline Fans & 80 & 80 & 80 \\
\hline Total & $3,093.4$ & $3,017.8$ & $3,035.4$ \\
\hline
\end{tabular}

SI Unit Conversions

$1 \mathrm{lb}=0.454 \mathrm{~kg}$

$260^{\circ} \mathrm{F}=126.7^{\circ} \mathrm{C}$ 
Table 16

BARLEY MALTING PLANT - ENERGY COST COMPARISON

\begin{tabular}{|c|c|c|c|}
\hline & $\begin{array}{l}\text { Base Design } \\
\text { (with corr. } \\
\text { allowance) }\end{array}$ & $\begin{array}{l}\text { Polymer } \\
\text { Concrete } \\
\text { Design } \\
\end{array}$ & $\begin{array}{l}\text { Epoxy } \\
\text { Lined } \\
\text { Design } \\
\end{array}$ \\
\hline Average Brine Flow Rate (lb/hour) & 239,000 & 239,000 & 239,000 \\
\hline Annual Heat Load (MBtu) & 192,000 & 192,000 & 192,000 \\
\hline $\begin{array}{l}\text { Total Capital Cost (Table 15), } \$ 1000 \\
\text { Annual Costs* }\end{array}$ & $\$ 3,093.4$ & $\$ 3,017,8$ & $\$ \quad 3,035.4$ \\
\hline Annualized Capital Cost (15\%) & $\$ 464,000$ & $\$ 452,700$ & $\$ 455,300$ \\
\hline Annual Brine Treatment Costs** & $\$ 34,300$ & $\$ 34,300$ & $\$ 34,300$ \\
\hline Annual Power Costs (Pumps and Fans) $* * *$ & $\$ 20,600$ & $\$ 20,600$ & $\$ 20,600$ \\
\hline Total Annual Cost & $\$ 518,900$ & $\$ 507,600$ & $\$ 510,200$ \\
\hline Energy Cost (Per MBtu) & $\$ 2.71$ & $\$ 2.65$ & $\$ 2.66$ \\
\hline
\end{tabular}

* Based on $18 \mathrm{hrs} /$ day and 333 days/yr of operation.

**Brine treatment costs of $\$ 25$ per million pounds.

$* * *$ Based on $150 \mathrm{HP}$, and $3 \xi / \mathrm{kWh}$ electricity costs.

SI Unit Conversions

$1 \mathrm{lb} \quad=0.454 \mathrm{~kg}$

$1 \mathrm{Btu} \quad=1.0546 \mathrm{~kJ}$

1 million $\mathrm{Btu}=1.0546 \mathrm{GJ}$

$1 \mathrm{HP} \quad=0.7457 \mathrm{~kW}$ 


\section{District Heating System}

As indicated in previous sections of this report, two different types of in-ground installations were considered for the district heating piping system. The first involved direct burial of the insulated pipes and protective jackets (Cases 2 through 5 ). The second involved placing of the insulated pipes into a concrete box or trench which would have a removable top for access (Cases 1 and 6). Capital cost comparisons are shown on Table 17 for the direct burial approach and on Table 18 for the concrete trench type of installation. Subtotals 1 and 2 on each of these tables indicate that significant cost savings could be obtained by using $A C$ or $P C$ pipe in lieu of carbon steel pipe for all sizes considered. A savings can also be obtained by using FRP pipe in the $3 \mathrm{in.} \mathrm{to} 8 \mathrm{in.}(76 \mathrm{~mm}-203 \mathrm{~mm}$ ) size range. However, for $16 \mathrm{in.} \mathrm{(406} \mathrm{mm)} \mathrm{pipe,} \mathrm{FRP} \mathrm{is} \mathrm{more} \mathrm{costly} \mathrm{than}$ steel.

Reference 2 indicates that due to the ease of future access and other considerations associated with the concrete trench, Case 1 is being selected as the preferred system in spite of the fact that its cost is the highest. It is interesting to note that Case 6 still has the advantages of the concrete box but may be $\$ 207,000$ (10 percent) cheaper than Case 1 due to the substitution of a PC pipe for the steel pipe inside.

Tables 19 and 20 compare the energy costs for the direct burial cases and the concrete trench cases respectively. A significant savings is gained by using the $A C$ and PC designs in lieu of the base metallic design regardless of whether the direct burial or the concrete trench approach is used. Table 19 indicates that FRP pipe would be more expensive than steel pipe. However, it should be noted that this 
TABLE 17

DISTRICT HEATING SYSTEM

CAPITAL COSTS FOR DIRECT BURIED PIPING

(in dollars)

\begin{tabular}{|c|c|c|c|c|c|}
\hline . & $\begin{array}{l}\text { Steel } \\
\text { (Case 2) }\end{array}$ & $\begin{array}{c}\text { FRP } \\
\text { (Case 3) }\end{array}$ & $\begin{array}{c}A C \\
\text { (Case 4) }\end{array}$ & $\begin{array}{l}\text { PC } \\
\text { Tensile } \\
600 \text { psi } \\
\text { (Case 5a) }\end{array}$ & $\begin{array}{l}\text { Strength } \\
450 \text { psi } \\
\text { (Case 5b }\end{array}$ \\
\hline $\begin{array}{l}\text { Geothermal Fluid } \\
\text { (16 in. Pipe) } \\
\text { Trenching, } \\
\text { Crossings, man- } \\
\text { holes and vaults }\end{array}$ & ystem & 104945 & 104745 & 104945 & 104945 \\
\hline Pipe Incl. Inst. & 360678 & 535027 & 292320 & 287407 & 322080 \\
\hline SUBTOTAL 1 & 465623 & 639972 & 397265 & 392352 & 427025 \\
\hline $\begin{array}{l}\text { Secondary Fluid Sy } \\
\text { (8 in. } 6 \text { in. } \& 3 \\
\text { Trenching, } \\
\text { Crossings, man- } \\
\text { holes and vaults }\end{array}$ & stem & 95665 & 95665 & 95665 & 95665 \\
\hline Pipe Incl. Inst. & 394407 & 233453 & 233464 & 209764 & 226437 \\
\hline SUBTOTAL 2 & 490072 & 329118 & 329120 & 305429 & 322102 \\
\hline TOTAL PIPING (I\&2) & 955695 & 969090 & 726394 & 697781 & 749126 \\
\hline $\begin{array}{l}\text { Wells \& Heat } \\
\text { Exchanger }\end{array}$ & 367278 & 367278 & 367278 & 367278 & 367278 \\
\hline SUBTOTAL 3 & $1,322,973$ & $1,336,368$ & $1,093,672$ & $1,065,059$ & $1,116,404$ \\
\hline $\begin{array}{l}\text { Engineering \& } \\
\text { Inflation } 115 \%\end{array}$ & 198446 & 200455 & 164051 & 159759 & 167461 \\
\hline TOTAL & $1,521,419$ & $1,536,823$ & $1,257,723$ & $1,224,818$ & $1,283,865$ \\
\hline
\end{tabular}

SI Unit Conversions

1 in. $=0.0254 \mathrm{~m}$

1 psi $=6.894 \mathrm{kPa}$ 
TABLE 18

DISTRICT HEATING SYSTEM

CAPITAL COSTS FOR PIPING IN CONCRETE TRENCH

(in dollars)

\begin{tabular}{|c|c|c|c|}
\hline & $\begin{array}{l}\text { Steel } \\
\text { (Case 1) }\end{array}$ & $\begin{array}{l}\text { PC } \\
\text { Tensile } \\
600 \text { psi } \\
\text { (Case 6a) }\end{array}$ & $\begin{array}{l}\text { Strength } \\
450 \text { psi } \\
\text { (Case 6b) }\end{array}$ \\
\hline $\begin{array}{l}\text { Geothermal Fluid System } \\
\text { (16 in. Pipe) }\end{array}$ & & & \\
\hline $\begin{array}{l}\text { Tunnel, crossings, manholes } \\
\text { and vaults }\end{array}$ & 409,722 & 409,722 & 409,722 \\
\hline Pipe Including Installation & 316,741 & 249,324 & 276,730 \\
\hline SUBTOTAL 1 & 726,463 & 659,046 & 686,452 \\
\hline $\begin{array}{l}\text { Secondary Fluid system } \\
\text { (8 in., } 6 \text { in. \& } 3 \text { in. Pipe) }\end{array}$ & & & \\
\hline $\begin{array}{l}\text { Tunnels, crossings, manholes } \\
\text { and vaults }\end{array}$ & 342,855 & 342,855 & 342,855 \\
\hline Pipe Including Installation & 294,205 & 181,535 & 193,770 \\
\hline SUBTOTAL 2 & 637,060 & 524,390 & 536,625 \\
\hline TOTAL PIPING $\left(\begin{array}{lll}1 & \& & 2\end{array}\right)$ & $1,363,523$ & $1,183,436$ & $1,223,077$ \\
\hline Wells and Heat Exchanger & 367,278 & 367,278 & 367,278 \\
\hline SUBTOTAL 3 & $1,730,801$ & $1,550,714$ & $1,590,355$ \\
\hline Engineering \& Inflation @ 15\% & 259,620 & 232,607 & 238,553 \\
\hline TOTAL & $1,990,421$ & $1,783,321$ & $1,828,908$ \\
\hline
\end{tabular}

SI Unit Conversions

1 in $=0.0254 \mathrm{~m}$

I $\mathrm{psi}=6.894 \mathrm{kPa}$ 
DISTRICT HEATING SYSTEM

ENERGY COST FOR DIRECT BURIED PIPING SYSTEMS

(in dollars)

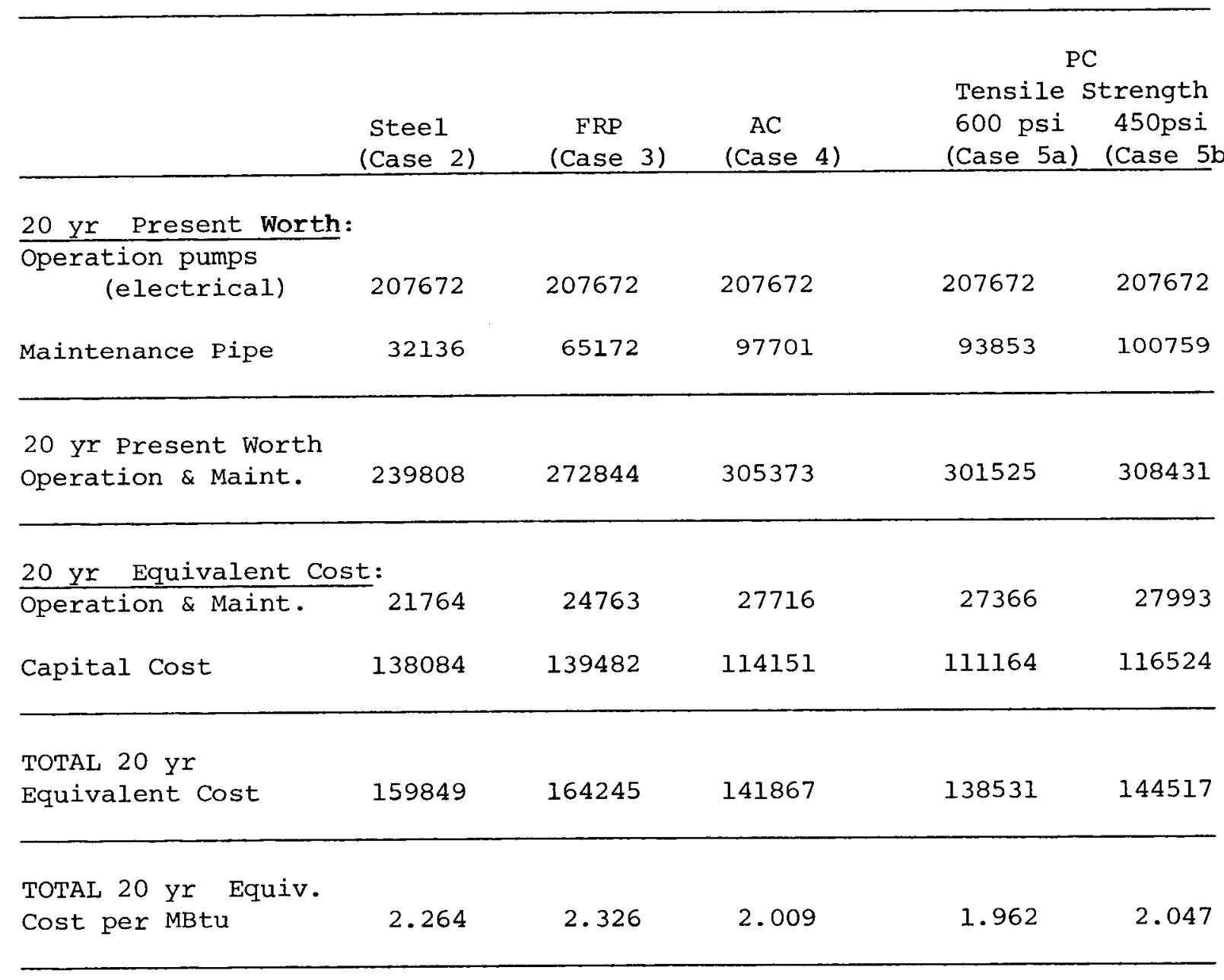

SI Unit Conversions

1 psi $=6.894 \mathrm{kPa}$

$1 \mathrm{MBtu}=1.0546 \mathrm{GJ}$ 
TABLE 20

DISTRICT HEATING SYSTEM

ENERGY COST FOR PIPING IN CONCRETE TRENCH

\begin{tabular}{|c|c|c|c|}
\hline & $\begin{array}{l}\text { Steel } \\
\text { (Case 1) }\end{array}$ & $\begin{array}{l}\text { P } \\
\text { Tensile } \\
600 \text { psi } \\
\text { (Case 6a) }\end{array}$ & $\begin{array}{l}\text { trength } \\
450 \text { psi } \\
\text { (Case 6b) }\end{array}$ \\
\hline 20 yr Present worth: & & & \\
\hline Operation Pumps (electrical) & 207672 & 207672 & 207672 \\
\hline Maintenance Pipe & 22907 & 42467 & 45133 \\
\hline $\begin{array}{l}20 \mathrm{yr} \text { Present Worth } \\
\text { operation and Maintenance }\end{array}$ & 230579 & 250139 & 252805 \\
\hline 20 yr Equivalent cost: & & & \\
\hline Operation and Maintenance & 20927 & 22703 & 22945 \\
\hline Capital Cost & 180651 & 161854 & 165992 \\
\hline Total 20 yr Equivalent Cost & 201578 & 184557 & 188937 \\
\hline $\begin{array}{l}\text { Total } 20 \text { yr Equivalent Cost } \\
\text { per MBtu }\end{array}$ & 2.855 & 2.614 & 2.676 \\
\hline
\end{tabular}

SI Unit Conversions

$1 \mathrm{psi}=6.894 \mathrm{kPa}$

$1 \mathrm{MBtu}=1.0546 \mathrm{GJ}$ 
table assumes that both the geothermal fluid system and the secondary fluid systems utilize FRP. However, as indicated on Table 17, a savings could be realized if only the secondary system (i.e., the smaller pipe sizes) were made of FRP. This savings would be about $\$ 0.05 / 10^{6}$ Btu $(\$ .047 / G J)$.

Evaluation of Results

How may these results be evaluated in terms of the potential benefit to be derived by the nation through the successful development of nonmetallic materials? One way to answer this question is to estimate the potential annual cost savings for the nation.

The total direct use of geothermal heat in industry, district heating, etc. as projected by $E G \& G{ }^{(3)}$ for the Rocky Mountain Basin and Range Region are presented in Table 21. It shows an anticipated direct use of 200,000 MBtu (211,000 GJ) in 1985 increasing to $2,500,000 \mathrm{MBtu}(2,637,500 \mathrm{GJ})$ in 2020. The total available energy from the potential direct use geothermal sources exceeds these numbers, but in the referenced report ${ }^{(3)}$ it has been assumed that competition from conventional energy sources and new ones like solar and biomass energy will limit the use of geothermal sources. The previous sections of this report show the savings per million Btu that can be achieved by switching from unprotected steel with an appropriate corrosion allowance to designs using nonmetallics. In the two industrial applications from the Coury report a savings of approximately 5$6 \xi / \mathrm{MBtu}$ (4.7-5.7\%/GJ) would be realized. Similarly, in the district heating project the savings would be 24-30\%/MBtu (22.7-28.4\%/GJ). It is reasonable to assume that the corresponding energy cost savings for all other direct use applications would also fall in the range of 5-30\%/MBtu 
TABLE 21

PROJECTED DIRECT UTILIZATION OF GEOTHERMAL ENERGY ROCKY MOUNTAIN BASIN AND RANGE REGION (3)

\begin{tabular}{ccc}
\hline Year & $\frac{\text { Projected Actual }}{\frac{\text { Direct Use }}{\text { Quad }}}$ & $\frac{\text { Potential }}{\text { Direct Use }}$ \\
1985 & 0.2 & 1.0 \\
2000 & 1.0 & 2.3 \\
2020 & 2.5 & 4.8 \\
\hline
\end{tabular}

Note: 1 quad $=10^{15} \mathrm{BTU}$

1 quad $=1.0545 \times 10^{18} \mathrm{~J}$ 
(4.7-28.4\%/GJ). On Table 22, this range of energy cost savings has been converted to an annual cost savings for the nation on the basis of the projected direct use data from Table 21. Thus, Table 22 indicates the impact that the development of nonmetallic materials may have on energy costs in the Rocky Mountain Basin and Range Region in future years. For instance, by the year 2000 a savings of from $\$ 50,000,000$ to $\$ 300,000,000$ per year could be saved. Of course, if other direct use geothermal resources are verified, such as in the Atlantic coastal Plain, additional savings would be achievable.

The annual maintenance costs shown on Tables 19 and 20 for the district heating system were calculated in accordance with the method used by LLC Geothermal consultants. As indicated, the maintenance costs for the nonmetallic piping systems are higher than for the metallic piping systems. However, it is reasonable to expect that these costs would be nearly the same for any of the piping systems selected. If the maintenance for all nonmetallic cases are assumed equal to that for the corresponding metallic design, the energy costs shown on Tables 19 and 20 would be reduced by the following amounts:

\begin{tabular}{|c|c|c|}
\hline \multirow[t]{5}{*}{19} & 2 & base \\
\hline & 3 & $\$ 0.042 / \mathrm{MBtu} \quad(\$ 0.040 / \mathrm{GJ})$ \\
\hline & 4 & $\$ 0.084 / \mathrm{MBtu} \quad(\$ 0.080 / \mathrm{GJ})$ \\
\hline & $5 a$ & $\$ 0.079 / \mathrm{MBtu} \quad(\$ 0.075 / \mathrm{GJ})$ \\
\hline & $5 b$ & $\$ 0.091 / \mathrm{MBtu} \quad(\$ 0.086 / \mathrm{GJ})$ \\
\hline \multirow[t]{3}{*}{20} & 1 & base \\
\hline & $6 a$ & $\$ 0.025 / \mathrm{MBtu} \quad(\$ 0.024 / \mathrm{GJ})$ \\
\hline & $6 b$ & $\$ 0.029 / \mathrm{MBtu} \quad(\$ 0.027 / \mathrm{GJ})$ \\
\hline
\end{tabular}

Thus, by assuming that the maintenance costs for the nonmetallic designs equal those for the metallic designs, 
Table 22

ENERGY COST SAVINGS VERSUS ANNUAL COST SAVINGS BASED ON PROJECTED DIRECT UTILIZATION OF GEOTHERMAL ENERGY (3) IN THE ROCKY MOUNTAIN BASIN AND RANGE REGION

Energy Cost Savings, \&/MBtu

5

Annual Cost Savings, million dollars per year: 1985 2000

10.0

50.0

125.0

2020

750

SI Unit Conversions

$1 \mathrm{MBtu}=1.0546 \mathrm{GJ}$ 
the maximum energy cost savings estimated for the district heating system would increase from 30 \%/MBtu $(28.4 \mathrm{c} / \mathrm{GJ})$ to $38 \mathrm{c} / \mathrm{MBtu}(36 \mathrm{c} / \mathrm{GJ})$.

Another interesting question raised by the results concerns the large difference in the energy cost reductions estimated for the sugar beet and barley malting plants versus those for the district heating system. However, it should be noted that the capital cost for piping per million Btu net output for the district heating case is much higher at $\$ 13.54 / \mathrm{MBtu} / \mathrm{yr}$ than the average $\$ 1.96 / \mathrm{MBtu} / \mathrm{yr}$ for the industrial projects. One of the main reasons for this difference is that the industrial projects operate from higher temperature wells, hence there is a greater temperature differential to work with. In fact, each gallon of geothermal fluid for the industrial projects carries 3.4 times more usable heat than in the case of the district heating system. Therefore, even if the dollar cost or cost savings were the same for each plant, the ratio of dollars/MBtu/yr would be higher for the district heating system. In a similar manner, the capacity factor would also have a significant effect on the dollar/MBtu/yr ratio. 


\section{REFERENCES}

1. Vorum, M., Coury, G. E., Goering, S. W., Fritzler, E. A.,"Non-Electric Utilization of Geothermal Energy in the San Luis Valley, Colorado"; Coury and Associates, Inc.; U. S. D.O.E. Contract No. EG-77-C-07-1626; September 1978 .

2. Lund, J. W., Lienau, P. J., Culver, G. G., Higbee, C. V., "Klamath Falls Geothermal District Heating-The Commercial District Design," Interim Report, LLC Geothermal Consultants, PON EG-77-N-03-1553, February, 1979 .

3. Schultz, R. J., Hanny, J. A., Knuth, W. H.," Geothermal Energy Market Potential in Industrial Processing," EG\&G Idaho Inc., 1979.

4. Sugama, T. and Kukacka, I. E., "The Effect of Dicalcium Silicate and Tricalcium Silicate on the Thermal stability of Vinyl-Type Polymer Concrete," Cement and Concrete Research 3, pp. 69-76 (1979).

5. Miller, L. G., Kunze, J. F., Sanders, R. D., "Asbestos Cement Pipeline Experience at the Raft River Geothermal Project," EG\&G Idaho Inc., 1979.

6. Verbal communication L. E. Kukacka, BNL, February 1979.

7. Burns and Roe Industrial Services Corp.; "Economic Assessment of Polymer Concrete Usage in Geothermal Power Plants;" for Brookhaven National Laboratory, Process Sciences Division, Department of Energy and Environment; November 1977.

8. Price Sheet "Cement Lined Pipe and Fittings" August 1, 1975. Pipe Lining and Coating Co., College Point, N. Y.

9. Kukacka, L. E., Rayfiel, R., Fontana, J. Arnold, G., Galen, B.,"Development of a Glass Polymer Composite Sewer Pipe from Waste Glass," BNL Progress Report No. 5, July-September 1977.

10. Robert Snow Means Company, Inc.; Building Construction Cost Data - 1978; 36th Edition.

11. Bezler, P. and Hendrie, J. M. et al; "Report on Polymer Concrete Applications Development for the Office of Saline Water-Design Studies on Multistage Flash Distillation Vessels;" Brookhaven National Laboratories, August 1978 . 
12. Nilson, A. H.; Design of Prestressed Concrete; Published by John Wiley and Sons, 1978 .

13. Roark and Young; Formulas for Stress and Strain; Published by McGraw-Hill: $\overline{5 \text { th }} \overline{\text { Edition; Page } 556}$ - Case 19b. 


\section{APPENDIX}

SOLID POLYMER CONCRETE (PC) VESSELS AND TANKS

Other investigators ${ }^{(11)}$ have developed a conceptual design and cost estimate for a PC pressure vessel designed for use in a desalination facility with pressures ranging from full vacuum up to 50 psig $(345 \mathrm{kPa})$. This section will discuss the results of an order-of-magnitude design and cost estimating calculation BRISC has made to assess the economic potential of such vessels in the applications described in previous sections of this report.

For purposes of this assessment, two vessels from the sugar beet refining plant described earlier have been selected for analysis. These vessels are Surge Tanks 1 and 2 . Surge Tank 1 - Sugar Beet Plant

For Surge Tank 1, which has an $80 \mathrm{psi}$ (552 kPa) design pressure, a prestressed PC design was examined. The allowable compressive stress for PC has been taken as 8100 psi $(55.9 \mathrm{MPa})(.45 \times 18000 \mathrm{psi})$ and Youngs Modulus as $6.5 \times 10^{6}$ psi $\left(44.8 \times 10^{3} \mathrm{MPa}\right)$. (11) The allowable tensile strength of the prestressing steel was taken as 168,000 psi ( $1158 \mathrm{MPa}$ ) based on a minimum tensile strength of 240,000 psi (1655 MPa) for ASTM A 421 prestressing wire. (12)

Vessel thickness was calculated first on the basis of the compressive membrane prestress which would have to be applied to balance the tensile hoop stresses applied in operation. This thickness was calculated on the basis of $f_{C}$ $=\mathrm{PR} / \mathrm{t}$ to be $0.9 \mathrm{in}$. $(23 \mathrm{~mm})$. A subsequent check for elastic instability (i.e., buckling) of the shell after prestressing, but before operation, has also been made using 
Reference 13. This indicates that a thickness of $1-5 / 8$ in. $(41 \mathrm{~mm})$ would be required to avoid buckling unless intermediate supports are used in the vessel.

on the basis of these calculations, the following specifications were selected for this vessel:

Material: PC

Diameter: $15 \mathrm{ft}(4.6 \mathrm{~m})$

Length: $20 \mathrm{ft}(6.1 \mathrm{~m})$

Thickness: $1-5 / 8$ in. (4l mm)

Circumferential Wires, Rings: 118 wires, $1 / 4 \mathrm{in}$ (6.4 (Post Tensioned)

$\mathrm{mm})$ dia. ASTM-421, 2 in. $(51 \mathrm{~mm})$ spacing along vessel length, post tension load $=15 \mathrm{kips}$ (6.8 t) per wire

Longitudinal Wires: 310 wires, $1 / 4$ in. $(6.4$ (Post Tensioned) $\mathrm{mm})$ dia. ASTM-A421, 1.8 in. $(45.7 \mathrm{~mm})$ circumferential spacing, post tension load $6.6 \mathrm{kips}$ $(2.4$ t)/wire

Prestressing Steel for Heads: 870 lbs $(395 \mathrm{~kg})$ of ASTM-A421 steel allowed

Costs for this vessel have been estimated on the basis of the following:

PC Cost

PC Cost (forms, etc.)

$=\$ 0.145 / 1 \mathrm{~b} \quad(\$ .32 / \mathrm{kg})$

Prestressing steel cost including post tensioning$$
=\$ 2 / \mathrm{ft}^{2}\left(\$ 21.50 / \mathrm{m}^{2}\right)
$$$$
=\$ 1.60 / 1 \mathrm{~b} \quad(\$ 3.52 / \mathrm{kg})
$$

The cost for the first item is higher than used in previous sections and is used here for conservatism. The costs for the second and third items are based on information contained in Reference 10 for structural shapes (beams, slabs, lift slabs, etc.). Therefore, these are at best only order-of-magnitude judgments for this application. The costs for the vessel based on the foregoing analysis are as follows : 


$\begin{array}{ll}\text { PC Material Cost } & =\$ 3,800.00 \\ \text { PC Casting Cost } & =2,700.00 \\ \text { Prestressing Steel Cost } & =\frac{4,500.00}{\quad \text { Total FOB Cost }}\end{array}$

In comparison, Table 2 shows costs of $\$ 30,850$ for the base design (metallic) and $\$ 27,100$ for the PC lined design. Thus, there appears to be a high probability that the prestressed PC design will offer a savings (perhaps 45-65\%) over the other alternative designs for this unit.

Surge Tank 2 - Sugar Beet Plant

Surge Tank 2 is designed to operate at atmospheric pressure. Since PC exhibits significant tensile strength, a reinforced concrete design has been considered for this vessel. Allowable stresses for PC have been taken as 8100 psi (55.9 MPa) compression and $720 \mathrm{psi}(5.0 \mathrm{MPa}$ ) tension. Yield stress for reinforcing steel has been assumed to be 60,000 psi (414 MPa).

The thickness of the concrete has been set to withstand hydrostatic pressure and the support induced stresses due to the deadweight of the vessel and its contents (assumed full of brine). Assuming that the vessel is simply supported along its length at three to four points, a PC thickness of 1-1/2 in. (38 mm) was selected. In addition, shear reinforcement (analogous to web reinforcement stirrups in a beam) has been considered by allowing for the installation of reinforcing rings (stirrups). These stirrups would be placed on 12 in. (305 mm) centers along the length of the tank. The design specifications for this tank are as follow:

Material: $P C$

Diameter: $20 \mathrm{ft}(19.7 \mathrm{~m})$

Length: $51 \mathrm{ft}(31 \mathrm{~m})$

Thickness: $1-1 / 2$ in. (38 mm) 
Shear Reinforcement: 51 stirrups, $1 / 2$ in. (12.7 mm) diameter bars, ASTM-A615-60 mat' 1,12 in. (305 mm) spacing along tank length

Costs for the reinforced PC tank have been calculated on the following basis:

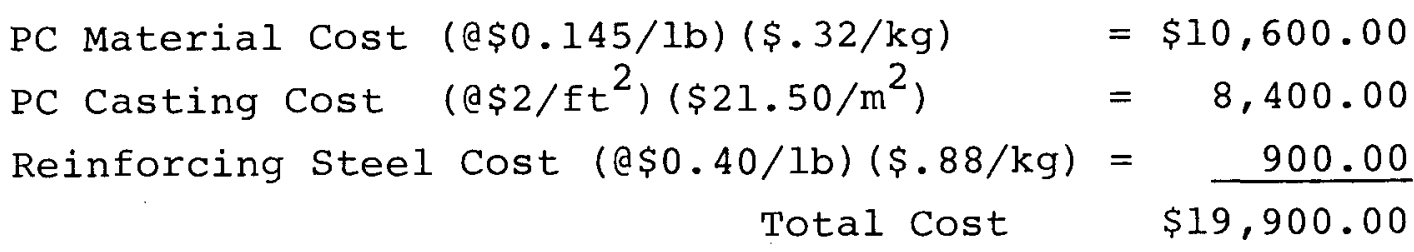

The cost for the first item is again considered conservative. The costs for the second and third items above have again been based on judgments derived from data in Reference 10. Therefore, the comments regarding estimating accuracy made in regard to the preceding analysis on surge Tank 1 also apply here. In comparison, the costs shown on Table 2 for the base design (all metallic) is $\$ 77,470$ and for the PC. lined design is $\$ 66,190$. Therefore, there is again a high probability that a significant cost savings (perhaps 50-70\%) could be obtained by using a reinforced PC tank in lieu of the other design alternatives for this application. Additonal Development Work Required

Reference 11 presents a fairly comprehensive review of the design, fabrication and construction problems to be resolved and the development efforts required before commercial prestressed or reinforced PC vessels of the type described above could be considered technically feasible. There is no need to reiterate them in this report. However, the analysis presented herein indicates that there is a significant incentive for the development of such units. 